\title{
NOTES
}

\section{DISCRIMINATORY DISCIPLINE OF UNION REPRESENTATIVES FOR BREACH OF THEIR "HIGHER DUTY" IN ILLEGAL STRIKES}

Remedies for illegal work stoppages are so unsatisfactory and counterproductive that Justice Powell once declared the aftermath of an illegal strike "a lawless vacuum." Although an employer may summarily discharge or suspend all participants in an illegal strike, ${ }^{2}$ the cost in lost production time may easily outweigh the benefit of strike deterrence. ${ }^{3}$ Therefore, the employer may choose to discipline, or to discipline more severely, only employees who are the union representatives ${ }^{4}$ of the rebellious work group.

At first glance, this selective punishment of union representatives appears to contravene sections $8(a)(1)$ and $8(a)(3)$ of the National Labor Relations Act (NLRA), ${ }^{5}$ which prohibit discriminatory

1. Complete Auto Transit, Inc. v. Reis, 451 U.S. 401, 423 (1981) (Powell, J., concurring in part $\&$ in the judgment).

2. See infra notes $20-21$ and accompanying text.

3. "[l]n a large wildcat strike, wholesale discharges are not practical because an cinployer cannot terminate all or most of his labor force without crippling production." Coinplete Auto Transit, Inc. v. Reis, 451 U.S. 401, 421 (1981) (Powell, J., concurring in part \& in the judgment). See infra note 15. Accord L. STESSIN, EMPLOYEe DisCIPIINE 211 (1960); Levy, Legal Responses to Rank-And-File Dissent: Restrictions on Union Officer Autonomy, 30 BUFFaLo L. REv. 663, 707-08 (1982). The cost of disciplining a small work group may also be prohibitive; for example, the company may need the group's product to fill a special order on time when replaceinent products or workers are unavailable. See J. KUHN, Bargaining IN GRIEVANCE SETTLEMENT 102 (1961).

4. See Levy, supra note 3, at 708.

The term "union representative" as used in this note includes union offcers, stewards, and committeemen.

5. These subsections provide:

(a) It shall be an unfair labor practice for an employer -

(1) to interfere with, restrain, or coerce employees in the exercise of the rights guaranteed in section 157 of this title;

(3) by discrimination in regard to hire or tenure of employment or any term or condition of employment to encourage or discourage membership in any labor organization .... .

29 U.S.C. § 158(a)(1) and (3) (1976).

The employer violates subsection (3) if he selectively punishes the union representative on the basis of his union status. See infra notes 71-73 and accompanying text. Conduct that violates subsection (3) also violates subsection (1) by imphication because union membership is a right 
discipline based solely on union status. Employers, however, justify the harsher punishment of union representatives by asserting either that as the leader of the work group, the union representative implicitly led the strike, or that the union representative had, and breached, an affirmative duty to dissuade the illegal strikers. In either case, the representative is presunied to have a higher duty than the rank-andfile, and the harsher punishment is supposedly not barred by sections $8(a)(1)$ and $8(a)(3)$ of the NLRA because it is not based on the representative's union status per se, but on his breach of the higher responsibility that status confers.

This note explores several possible bases of the union representative's alleged higher duty in an illegal strike and traces the movement of the National Labor Relations Board (NLRB) away from a theory of responsibility predicated on the union representative's status. ${ }^{6}$ The note then examines the recent decisions of several federal circuit courts which, like the NLRB, first adopted and then rejected a status-based theory of responsibility. ${ }^{7}$ These courts now endorse, to varying degrees, an analysis that identifies the collective bargaining agreement as the source of the representative's higher duty in the context of an illegal strike. The note discusses the advantages of this trend and encourages a niore coniplete adoption of the contract-based theory of responsibility; ${ }^{8}$ lowever, it cautions that undue reliance on an arbitrator's construction of the contract can lead to an unwarranted revitalization of the status-based theory. ${ }^{9}$

\section{Predication of the Representative's Higher Duty on His UNION STATUS}

Concerted activity without union approval is inconsistent with exclusive representation ${ }^{10}$ and is unprotected by the NLRA. Therefore,

guaranteed by section 7 of the Act, 29 U.S.C. $\$ 157$ (1976). The Seventh Circuit terms this a "derivative violation" of subsection (1) and has held that the same facts prove violations of subsections (I) and (3) in such a case. Indiana \& Mich. Elec. Co. v. NLRB, 599 F.2d 227, 229 n.2 (7th Cir. 1979). See R. Gorman, Basic Text on Labor Law 132 (1976).

6. See infra notes 20-59 and accompanying text.

7. See infra notes 60-143 and accoinpanying text. The Supreme Court has recently granted certiorari on one of these cases, Metropolitan Edison Co. v. NLRB, 663 F.2d 478 (3d Cir. 1981), cert. granted, 102 S. Ct. 2926 (1982).

8. See infra notes $144-48$ and accornpanying text.

9. See infra notes $151-84$ and accoinpanying text.

10. R. GORMAN, supra note 5, at 307-08. In Medo Photo Supply Corp. v. NLRB, 321 U.S. 678 (1944), the Court held that an employer who negotiated directly with the employecs and ignored the union contravened "the essential principle of collective bargaining," id. at 684, and violatcd sections 8(a)(1), 8(a)(5), and 9(a) of the Act, 29 U.S.C. $\$ \$ 158(a)(1), 158(a)(5) \& 159$ (a) (1976), by imterfering with protected rights, refusing to bargain with the union, and failing to 
the employer may discipline or discharge wildcat strikers ${ }^{11}$ without committing an unfair labor practice. ${ }^{12}$ In addition, many collective bargaining agreements contaim a no-strike clause 13 that "establishes a rule of conduct or condition of employment the violation of which by em-

acknowledge the union as the exclusive representative of the employees. 321 U.S. at $683-84,687$. See Emporium Capwell Co. v. West Addition Community Org., 420 U.S. 50, 67.69 (1975).

11. A "wildcat" strike is a strike by unionized employees without union authorization. $R$. GORMAN, supra note 5, at 307. "Quickie" walkouts, sickouts, and slowdowns may also be unauthorized work stoppages, but they usually are of shorter duratiou, or imvolve fewer workers, than a full-scale wildcat strike.

12. See, e.g., NLRB v. Draper Corp., 145 F.2d 199, 202 (4th Cir. 1944). If the employees were not unionized, however, their concerted activity would be protected under section 7 of the National Labor Relations Act, 29 U.S.C $\$ 157$ (1976). See NLRB v. Washington Aluminum Co., 370 U.S. 9, 14-15 (1962).

In the 1960s, there was some indication that a wildcat strike in support of an established union policy would be cousidered protected activity. See NLRB v. R.C. Can Co., 328 F.2d 974 (5th Cir. 1964). In such a case, the principle of exclusive representation is not violated because the wildcat strikers are in harmony with union objectives. Id. at 979 . The Fifth Circuit repudiated R.C. Can in NLRB v. Shop Rite Foods, Iuc., 430 F.2d 786, 790-91 (5th Cir. 1970), and the Supreme Court unequivocally rejected the theory in Einporium Capwell Co. v. West Addition Community Org., 420 U.S. 50, 67.69 (1975) (unauthorized picket line to protest employer's racial discrimination is unprotected despite union antidiscrinimation policy). See R. GoRMAN, supra note 5 , at $307-10$.

13. For an example of a no-strike clause, see infra note 131. A no-strike clause is typically the quid pro quo for an arbitration clause. Complete Auto Transit, Inc. v. Reis, 451 U.S. 401, 418 (1981) (Powell, J., concurring im part \& in the judgmeut); Buffalo Forge Co. v. United Steelworkers, 428 U.S. 397, 407 (1976); Boys Markets, Inc. v. Retail Clerks Local 770, 398 U.S. 235, 248 (1970); United Steelworkers v. American Mfg. Co., 363 U.S. 564, 567 (1960); Textile Workers v. Lincoln Mills, 353 U.S. 448, 455 (1957). The union gives up its right to call a strike or other work stoppage during the term of the agreenient, but the loss of this traditional means of protesting unfair labor practices is compensated by the union's power to force the employer to arbitrate grievances.

Courts and the NLRB will infer the existeuce of a no-strike clause if the collective bargaining agreement contams an arbitration clause. See Consolidation Coal Co., 263 N.L.R.B. No. 188, at 47-48 (1982) (Member Hunter, dissenting). If a no-strike clause were not inferred, the employer would not receive his due im return for his promise to arbitrate. See, e.g., Buffalo Forge Co. v. United Steelworkers, 428 U.S. 397, 407 (1976); Gateway Coal Co. v. UMW, 414 U.S. 368, 382 (1974); International Blid. of Teamsters Local I74 v. Lucas Flour Co., 369 U.S. 95, 105 (1962); Blue Diamond Coal Co. v. UMW, 436 F.2d 551, 554-55 (6th Cir. 1970) (court infers no-strike clause even where contract did not characterize arbitration as "exclusive" means of scttling disputes), cert. denied, 402 U.S. 930 (1971); J.P. Wetherby Constr. Corp., 182 N.L.R.B. 690, 696-97 (1970) (opmion of trial examiner, affirmed by Board).

The parties to a collective bargaiming agreement may contract out of an inplied no-strike clause, but the Supreme Court has ruled that "[a]bsent an explicit expression of such an intention, however, the agreement to arbitrate and the duty not to strike should be construed as having coterminous apphication." Gateway Coal, 414 U.S. at 382. The repeal of a no-strike clause in an earlier agreement does not suffice to prevent courts from finding an inplied duty not to strike; courts have held that in such circumstances a strike over an arbitrable dispute breaches the collective bargaining agreemeut. See Old Ben Coal Corp. v. Local 1487, UMW, 457 F.2d 162, 164 (7th Cir. 1972); Lewis v. Beuedict Coal Corp., 259 F.2d 346, 351 (6th Cir. 1958), modified, 361 U.S. 459 (1960). 
ployees justifies discipline or discharge." 14 In the exercise of its broad discretionary power to discipline employees who breach the no-strike clause, the employer may choose not to discipline anyone or to discipline only select participants. ${ }^{15}$ Presumably, however, section 8(a)(3) of the NLRA ${ }^{16}$ imposes some limitation on whom the employer may choose to pumish.17

In a typical case, a union representative whose work group has staged an illegal work stoppage is either the only participant pumshed for the group's activity, or is pumished more severely than other participants. The representative alleges that the employer has discriminated against him based on his umion status in violation of sections $8(a)(1)$ and (3) of the NLRA, ${ }^{18}$ and the employer claims that the representative's higher responsibility im the face of an illegal strike justifies his harsher pumshment. In its frequent efforts during the past thirty years to resolve this issue, the NLRB has explored several possible bases for the umion representative's alleged higher responsibility. ${ }^{19}$

14. Atkinson v. Sinclair Ref. Co., 370 U.S. 238, 246 (1962). See Mastro Plastics Corp. v. NLRB, 350 U.S. 270, 280 (1956); NLRB v. Rockaway News Co., 345 U.S. 71, 80 (1953); NLRB v. Sands Mfg. Co., 306 U.S. 332, 344 (1939); Gould, Inc. v. NLRB, 612 F.2d 728, 732 (3d Cir. 1979), cert. denied, 449 U.S. 890 (1980); Food Fair Stores, Inc. v. NLRB, 491 F.2d 388, 395 (3d Cir. 1974).

15. See, e.g., Consolidation Coal Co., 263 N.L.R.B. No. 188, at 6 (1982); Miller Brewing Co., 254 N.L.R.B. 266, 267 (1981) (opinion of administrative law judge, affirmed by Board); Rogate Indus., Inc., 246 N.L.R.B. 898, 898-99 (1979); Gould Corp., 237 N.L.R.B. 881, 882 (1978) (Meinber Truesdale, concurring in part \& dissenting in part), enforcement denied, 612 F.2d 728 (3d Cir. 1979), cert. denied, 449 U.S. 890 (1980); Chrysler Corp., Dodge Truck Plant, 232 N.L.R.B. 466, 474 (1977) (opinion of administrative law judge, affirmed by Board); J.P. Wetlrerby Constr. Corp., 182 N.L.R.B. 690, 697 n.31 (1970). Cf. NLRB v. Fansteel Metallurgical Corp., 306 U.S. 240, 259 (1939) (company may selectively reemploy illegal strikers).

To the extent that the employer does not discipline any of the participants in a work stoppage, he coudones the illegal activity. This is not uncommon, see I. HowE \& B. WIDDICK, THE UAW AND WALTER REUTHER 241-42 (1973), perhaps because in certain circumstances the cost of the work stoppage is less than the cost of punishmeut (measured in terms of demoralization and lost unanpower). See supra note 3; see also Metropolitan Edison Co. v. NLRB, 663 F.2d 478, 481' (3d Cir. 1981), cert. granted, 102 S. Ct. 2926 (1982); Gould, Inc. v. NLRB, 612 F.2d 728, 732 (3d Cir. 1979), cert. denied, 449 U.S. 890 (1980); Indiana \& Mich. Elec. Co. v. NLRB, 599 F.2d 227, 230 (7th Cir. 1979).

16. 29 U.S.C. $\$ 158(a)(3)$ (1976).

17. As the NLRB stated in Precision Castings Co., 233 N.L.R.B. 183 (1977):

The fact that the disciplined einployees participated in an unauthorized strike in breach of a vahid contract provision does not legitimize . . . [the employer's] action in this situation. . . . [The einployer's] freedom to discipline anyone remamed unfettered so long as the criteria employed were not union-related. . . . [D]iscrimination directed against an employee on the basis of his or her holding umion office is contrary to the plaim meaning of Section 8(a)(3) and would frustrate the pohicics of the Act if allowed to stand.

Id. at 183-84 (footnote ounitted)

18. 29 U.S.C. $\S \S 158(a)(1),(3)$ (1976).

19. For an alternative review and analysis of the Board's position, see Rummage, Union Officers and Wildcat Strikes: Freedom from Discriminatory Discipline, 4 INDUS. REL. L.J. 258, 262-77 (1981). See also Levy, supra note 3, at 711-12 \& nn.273-77 (criticism of Rummage's analysis). 


\section{A. The Theories of Implicit and Negative Leadership and the Exchange Theory.}

Although it would violate sections 8(a)(1) and (3) of the NLRA to predicate the discriminatory discipline of a representative on his union status, it is arguably permissible to discipline more severely a umion representative who fails to discharge some special duty that accrues to his position. The distinction requires one to walk a narrow line between predication of fault on status and predication of fault on responsibilities that accrue to that status. Nevertheless, the NLRB and various Board members have repeatedly attempted to perform this difficult gymnastic.

1. Implicit and Negative Leadership. Before its 1977 decision im Precision Castings Co. ${ }^{20}$ the NLRB rehed on several status-based theories of responsibility to justify the discriminatory discipline of union representatives who participate im illegal work stoppages. In some cases, participation alone justified the discriminatory punishment. ${ }^{21}$ In other cases, the Board has held that because a steward, by virtue of his position, is the natural leader of his work group, his participation in an illegal stoppage implies that he led it."22 Although this theory of "implicit leadership" has some historical and empirical support, ${ }^{23}$ it does not warrant an irrebuttable presumptive inference of leadership froin participation. Some illegal work stoppages apparently result froin a

20. 233 N.L.R.B. 183 (1977). For a discussion of Precision Castings, see infra text accompanying notes $39-41$.

21. See, e.g., Russell Packing Co., 133 N.L.R.B. 194, 196 (1961). The Board upheld the discriminatory discharge of the chief steward in Russell Packing despite the finding that the steward tried to persuade the employees to return to work. $Y d$. at 197-98.

22. See, e.g., Chrysler Corp., Dodge Truck Plant, 232 N.L.R.B. 466, 475 (1977); Stockham Pipe Fittings Co., 84 N.L.R.B. 629, 629 (1949),

It is an accepted rule that if a union representative has actually led, organized, or incited an illegal work stoppage, more severe purishment is warranted and does not violate section 8(a)(3). See, e.g., Szewczuga v. NLRB, No. 81-1054, slip op. (D.C. Cir. Aug. 17, 1982); Metropolitan Edison Co. v. NLRB, 663 F.2d 478, 482 n.2 (3d Cir. 1981), cert. granted, 102 S. Ct. 2926 (1982); Consolidation Coal Co., 263 N.L.R.B. No. 188, at 11 n.12 (1982); Miller Brewing Co., 254 N.L.R.B. 266, 279 (1981) (opinion of administrative law judge, nodified by Board); Guy F. Atkinson Co., 251 N.L.R.B. 277, 280 (1980); Armour-Dial, Inc., 245 N.L.R.B. 959, 959 (1979), enforcement denied on other grounds, 638 F.2d 51 (8th Cir. 1981).

23. In the early years of unionization, which culminated in the militant unionism of the 1930s, the steward functioned as a sort of field marshal, wielding his power to call a local or sublocal strike. See I. HowE \& B. WIDDICX, supra note 15, at 238; J. KUHN, supra note 3, at 12; S. PECK, The RANK-AND-FILE LeAder 31 (1963). There is reason to believe that some stewards continue to use disruptive tactics to wage what is tantamount to a guerrilla war against management. See, e.g., Chrysler Corp., Dodge Truck Plant, 232 N.L.R.B. 466, 475 (1977) (opinion of administrative law judge, affirmed by Board) (steward engaged in "labor relations brinksmanship"); N. Chamberlain, LABor 250 (1958); J. KuHN, supra note 3, at 50-53; D. Miller \& W. FORM, INDUSTRIAL SOCIOLOGY 397-98, 400 (1951). 
kind of spontaneous combustion of long-smoldering worker discontent, ${ }^{24}$ and other stoppages are led by "hot-heads" within the rank-andfile. ${ }^{25}$ In such cases, it would seem unjustifiable to hold the steward primarily (or even equally) hable for inciting the strike. Most ineinbers of the Board no longer endorse the theory of implicit leadership, although it echoed for years through the strident dissents of Member Penello. 26

During the years in which the NLRB endorsed soine status-based theory of responsibility, it nevertheless rejected the arbitration theory of "negative leadership."27 Under this theory, union representatives "have an affirmative duty to take steps to see that their constituents live up to the Umion's contractual undertaking," 28 and a representative's failure to discharge this duty justifies his dismissal. The theory of imphicit leadership and the theory of negative leadership both predicate the union representative's liability for an illegal work stoppage on his status. There is, however, a significant distimction between the two theories. The theory of imphcit leadership exposes the union representative to a greater risk of discipline than the rank-and-file, but only if he violates the contractual obligation that the no-strike clause explicitly imposes on all employees. By contrast, the theory of negative leader-

24. See, eg. , J. KUHN, supra note 3, at 39-41; D. MiLLER \& W. FORM, supra note 23, at 387; Atleson, Work Group Behavior and Wildcat Strikes: The Causes and Functions of Industrial Disobedience, 34 OHio ST. L.J. 751, 811 (1973). For a general discussion of the causes and dynamics of wildcat strikes, see A. GouldNer, WILDCAT STRIKES (1954).

25. See J. KuHN, supra note 3, at 39-41.

26. See, e.g., Miller Brewing Co., 254 N.L.R.B. 266, 269 (1981) (Member Penello, dissenting); Metropolitan Edison Co., 252 N.L.R.B. 1030, 1031 (Member Penello, dissenting), enforccd, 663 F.2d 478 (3d Cir. 1981), cert. granted, 102 S.Ct. 2926 (1982); Babcock \& Wilcox Co., 249 N.L.R.B. 739, 741-42 (1980) (Member Penello, dissenting); Midwest Precision Castings Co., 244 N.L.R.B. 597, 600 (1979) (Member Penello, concurring); see also infra note 42. In Midwest Precision the majority of the Board agreed that the steward's discriminatory discipline was warranted by her leadership role, but where the majority looked to the steward's specific acts to demonstrate her leadership, id. at 598, Member Penello found that the steward was the leader of the slowdown "by the very nature of . . . [her] position" as steward, id. at 600 . For a discussion of Midwest Precision, see infra notes 43-54 and accompanying text.

In their initial decisions on this issue, the Third and Seventh Circuits made passing references to the thcory of iniplicit leadership, see Gould Inc. v. NLRB, 612 F.2d 728, 730 n.2, 732 n.4 (3d Cir. 1979), cert. denied, 449 U.S. 890 (1980); Indiana \& Micl. Elec. Co. v. NLRB, 599 F.2d 227, 231 \& n.9 (7th Cir. 1979), but the theory does not survive in their inore recent opinions, see Metropohtan Edison Co. v. NLRB, 663 F.2d 478 (3d Cir. 1981), cert. grantcd, 102 S.Ct. 2926 (1982); Hammermill Paper Co. v. NLRB, 658 F.2d 155 (3d Cir. 1981), petition for cert. filed, 50 U.S.L.W. 3703 (U.S. Jan. 1, 1982) (No. 81-1438); C.H. Heist Corp. v. NLRB, 657 F.2d 178 (7th Cir. 1981).

27. The concept of negative leadership was "developed by the inpartial chairman of the Chrysler-UAW appeals board in a series of arbitration awards which have been issued over the years." Chryslez Corp., Dodge Truck Plant, 232 N.L.R.B. 466, 470 n.11 (1977) (opinion of administrative law judge, affirmed by Board).

28. Id. 
ship imposes an entirely different, affirmative duty on the union representative: he must actively dissuade the illegal strikers even if this obligation is not mentioned in the collective bargaining agreement. The Board has consistently rejected the theory of negative leadership, even when it endorsed the theory of implicit leadership, because the former theory imposes "different and greater . . . responsibilities" on the union representative than on the rank-and-file. ${ }^{29}$

2. The Exchange Theory. In his dissents to recent Board decisions involving the discriminatory discipline of union representatives who participate im illegal strikes, Member Penello also relied on an exchange theory to justify predication of a union representative's duty on his status. ${ }^{30}$ Certain benefits, notably superseniority, ${ }^{31}$ often accrue to union stewardship. Member Penello reasoned that the steward receives these benefits $\mathrm{s}^{32} \mathrm{im}$ exchange for the assumption of duties above those of the rank-and-file to administer the collective bargaining agreement, including the duty to take affirmative steps to enforce the no-strike clause. ${ }^{33}$ Therefore, "an employer can lawfully discipline a union offi-

29. Chrysler Corp., Dodge Truck Plant, 232 N.L.R.B. 466, 475 n.20 (1977) (opinion of administrative law judge, affirmcd by Board). See also Armour-Dial, Inc., 245 N.L.R.B. 959,960 n.7 (1979), enforcement denied, 638 F.2d 51 (8th Cir. 1981).

30. See Bethlehem Steel Corp., 252 N.L.R.B. 982, 982 (1980) (Member Penello, dissenting), enforcement denied sub nom. Fournelle v. NLRB, 670 F.2d 331 (D.C. Cir. 1982); Mctropolitan Edison Co., 252 N.L.R.B. 1030, 1031 (1980) (Member Penello, dissenting), enforced, 663 F.2d 478 (3d Cir. 1981), cert. granted, 102 S. Ct. 2926 (1982). Midwest Precision Castings Co., 244 N.L.R.B. 597, 600 (1979) (Member Penello, concurring); Gould Corp., 237 N.L.R.B. 881,884 (1978) (Mcmber Penello, dissenting), enforcement denied, 612 F.2d 728 (3d Cir. 1979), cert. denied, 449 U.S. 890 (1980).

For additional criticisin of this theory, see Levy, supra note 3, at 713, 717-18; Rummage, supra note 19 , at $272-73$.

31. Supersemiority is a special employnent status that assures that stewards will not be laid off before other workers, thereby preventing employers from using economically necessary layoffs as an opportunity to rid themselves of union activists.

32. Although Menber Penello often invoked the "battery of benefits and protections" which the steward receives, see Gould Corp., 237 N.L.R.B. 881,884 (1978) (Member Penello, dissenting) (einphasis omitted), enforcement denied, 612 F.2d 728 (3d Cir. 1979), cert. denied, 449 U.S. 890 (1980), it is not clear what benefits, besides superseniority, are included in that "battery." In Gould, Member Penello cited two earlier Board decisions which lold that members of a grievance committee can insult managers during the course of grievance negotiations without fear of reprisal by discharge. Id. at 884 (citing Crown Cent. Petroleun Corp., 177 N.L.R.B. 322 (1969); Thor Power Tool Co., 148 N.L.R.B. 1379 (1964)). As another writer has noted, see Levy, supra note 3, at 717 , this benefit or protection is available to all einployees, not only union representatives, see Beltcher Mfg. Corp., 76 N.L.R.B. 526, 527 (1948). Therefore, the steward's so-called battery of benefits reduces to the grant of supersemiority.

33. Bethlehein Steel Corp., 252 N.L.R.B. 982, 982 (1980) (Member, Penello, dissenting), enforcement denied sub nom. Fournelle v. NLRB 670 F.2d 331 (D.C. Cir. 1982); Midwest Precision Castings Co., 244 N.L.R.B. 597, 600 (1979) (Member Penello, concurring). 
cial more harshly than other employees for participating in an unprotected strike."34

The exchange theory is problematic for several reasons. First, not all union representatives receive the same benefits. ${ }^{35}$ Therefore, proper application of the exchange theory would require balancing the individual representative's benefits against the action he took to dissuade illegal strikers; in theory, the fewer benefits he enjoys, the less he is obhigated to do. The exchange theory has never been applied in this manner, which suggests that its value is more syinbolic than legal. This is not to say that the exchange theory should be taken inore seriously; where feasible, general rules are preferable to such case-by-case, discretionary balancing tests.

Even assuming that the exchange theory is sound, it need not yield the affirmative duty suggested by Member Penello. It is equally plausible that in exchange for his perquisites of office, the representative lias a duty to handle employee grievances conscientiously and to inform employees of the terms of the collective bargaining agreement. Nothing necessitates adding to those responsibilities the duty to take affirmative steps to halt an illegal work stoppage; it is not axionnatic that the union representative must police the no-strike clause. Furtlermore, even if the union representative were to receive his benefits in exchange for policing the no-strike clause, the proper remedy for a representative's failure to discharge his duty to dissuade illegal strikers would be the revocation of his benefits, not suspension or discharge. Any duty to dissuade under this theory should accrue to the union representative's status as a representative, not as an employee. Tlus, it would be inappropriate under tlie exchange theory for him to be punislied as an employee for his failure as a union representative. ${ }^{36}$

Fimally, the exchange theory presupposes that the union representative receives the so-called "benefits" in excliange for his performing certam tasks. This is not necessarily so. It is arguable that the "benefits" are not really a form of consideration or payıent, but are a necessary precondition for the exercise of union representation. For exainple, superseniority nuakes it more difficult for an employer to discharge a union representative. By securing this protection, the union saves itself the time and cost necessary to prove that its representative has been discharged in retaliation for being an active, effective advo-

34. Bethlehem Steel Corp., 252 N.L.R.B. 982, 982 (1980) (Member Penello, dissenting), enforcement denied sub nom. Fournelle v. NLRB, 670 F.2d 331 (D.C. Cir. 1982).

35. Only forty percent of the union representatives governed by major collective bargaining agreements enjoy superseniority, the most valuable of the representative's benefits and the one stressed by Member Penello. U.S. Bureau of Labor Statistics, Dep't of Labor Bull. No. 2065, Characteristics of Major Collective Bargaining Agreements 90 (1980).

36. See infra note 152 . 
cate of employee rights. In this sense, superseniority is not a benefit granted by the employer to the representative in return for his obligation to dissuade illegal strikers; rather, it is a concession made by management to a strong umion that wishes to increase its efficiency and to give its representatives the optimal conditions for the exercise of their union responsibilities. ${ }^{37}$

\section{B. The NLRB's Rejection of the Status-Based Theory of Responsibility.}

The NLRB's position on discriminatory discipline of union representatives changed suddenly in 1977.38 In Precision Castings Co., 39 the panel held that an employee's stewardship does not warrant his "be[ing] held to a greater degree of accountability for participating in the [illegal] strike," because "discrimination directed agamst an einployee on the basis of his or her holding union office is contrary to the plain meaning of [s]ection 8(a)(3) and would frustrate the policies of the [NLRA]." 40 With this holding, the Board firmly rejected the statusbased theory of responsibility to which it had subscribed since 1949.41

37. See Brief for Respondent at 10 n.5, Hammermill Paper Co. v. NLRB, 658 F.2d 155 (3d Cir. 1981), petition for cert. fled, 50 U.S.L.W. 3703 (U.S. Jan. 1, 1982) (No. 81-1438). In Hammermill, the Board (respondent) argued that superseniority, like time off with pay to handle grievances, is a benefit which is "confined to a legitimate and agreed-upon need . . . [and] clearly do[es] not justify exposing stewards to a countervailing set of obligations unilaterally devised and enforced by the employer." Id.

38. Contra Rummage, supra note 19. Rummage argues that the Board has never deviated from its position that a union representative's status may be taken into consideration in evaluating whether his behavior warranted more severe discipline. Id. at $262,269,279$. This is the theory of implicit leadership mentioned above. See supra notes 20-29 and accompanying text. As Rummage realizes, see Rummage, supra note 19, at 280-83, courts have agreed that prior to Precision Castings, the Board condoned a status-based theory of responsibihity. The same courts agreed that Precision Castings marked a radical change in the Board's position. See, e.g., Gould, Inc. v. NLRB, 612 F.2d 728, 732 \& n.4 (3d Cir. 1979), cert. denied, 449 U.S. 890 (1980); Indiana \& Micl.. Elec. Co. v. NLRB, 599 F.2d 227, 230 (7th Cir. 1979); see also Consolidation Coal Co., 263 N.L.R.B. No. 188, at 39 (1982) (Member Hunter, dissenting). In its more recent decisions, the Board has continued to follow Precision Castings. See, e.g., Consolidation Coal Co., 263 N.L.R.B. No. 188 (1982); Bethlehem Steel Corp., 252 N.L.R.B. 982 (1980), enforcement denied sub nom. Fournelle v. NLRB, 670 F.2d 331 (D.C. Cir. 1982); Metropotitan Edison Co., 252 N.L.R.B. 1030 (1980), enforced, 663 F.2d 478 (3d Cir. 1981), cert. granted, 102 S. Ct. 2926 (1982). But see infra notes 43-54 and accompanying text (discussion of Midwest Precision Castings Co., 244 N.L.R.B. 597 (1979)). For criticism of Rummage's view, see Levy, supra note 3, at 711-12 \& nn. 273-77.

39. 233 N.L.R.B. 183 (1977).

40. Id. at 184 (footnote omitted).

41. See Gould Corp., 237 N.L.R.B. 881, 886 (1978) (Meniber Penello, dissenting), enforcement denied, 612 F.2d 728 (3d Cir. 1979), cert. denied, 449 U.S. 890 (1980). In its decisions which followed Precision Castings, the Board tried, unconvimcingly, to distinguish its earlier status-based decisions. See, e.g., Indiana \& Mich. Elec. Co., 237 N.L.R.B. 226, 228 (1978), enforcement denied, 599 F.2d 227 (7th Cir. 1979), cert. denied, 444 U.S. 1014 (1980). 
The reorientation was not unanimous. ${ }^{42}$ In Midwest Precision Castings Co. ${ }^{43}$ the Board held that the discriminatory discharge of a steward for her role in a work slowdown did not violate section $8(a)(3), 44$ but the Board rendered its "unanimous" decision in four separate opinions (plus a footnote to Member Jenkins's opinion in which Member Murphy stated her position). The steward in Midwest Precision was discharged because she instructed another employee to slow down her production rate. ${ }^{45}$ Meinber Jenkins, who wrote the opinion in Midwest Precision, found that the steward had led the slowdown by commanding an employee to work more slowly and was therefore outside the protection of section $8(a)(3) . .^{46}$ Meinber Jenkins dist-

Precision Castings relied on Pontiac Motors Div., Gen. Motors Corp., 132 N.L.R.B. 413 (1961), which lield that a no-strike clause alone does not warrant status-based discipline of union representatives, $i d$. at 415 . As Member Truesdale correctly pointed out, however, the union committeeman in Pontiac Motors, who was discriminatorily punished for his failure to persuade some employees to work overtime, did not himself refuse to work; this distinguishes Pontiac Motors from Precision Castings. 237 N.L.R.B. at 882 (Member Truesdale concurring in part \& dissenting in part). Because the representative did not participate in the work stoppage, Pontiac Motors is not imconsistent with its contemporary, Russell Packing Co., 133 N.L.R.B. 194 (1961), which held that participation alone is sufficient to expose a union representative to more severe discipline, $i d$ at 196. See supra note 21 and accompanying text.

42. In the four years between Precision Castings and his departure from the Board, Member Penello issued a steady stream of dissents to protest the Board's current position. See supra note 26 and accompanying text. The most thorough exposition of Member Penello's position appears in Gould Corp., 237 N.L.R.B. 881, 882-88 (1978) (Member Penello, dissenting), enforcement denied 612 F.2d 728 (3d Cir. 1979), cert. denied, 449 U.S. 890 (1980). For detailed criticism of Member Penello's opinion in Gould, see Rummage, supra note 19, at 270-75.

Meinber Truesdale, who is also no longer on the Board, was similarly discontented. See, e.g., Midwest Precision Castings Co., 244 N.L.R.B. 597, 602 (1979) (Member Truesdale, concurring); Gould Corp., 237 N.L.R.B. 881, 881-82 (1978) (Member Truesdale, concurring in part \& dissenting in part), enforcement denied, 612 F.2d 728 (3d Cir. 1979), cert. denied, 449 U.S. 890 (1980). Member Truesdale lad fewer opportunities than Member Penello to voice his dissent because many of the discriminatory discipline cases were decided by three-member panels of the Board, pursuant to 29 U.S.C. § 153(b) (1976), and Member Penello was more frequently part of the panel.

43. 244 N.L.R.B. 597 (1979).

44. 29 U.S.C. $\$ 158(a)(3)$ (1976).

45. The no-strike clause in the collective bargaining agreement in Midwest Precision included the customary language forbidding any "strike, boycott or slowdown." 244 N.L.R.B. at 597.

46. The steward defended lier action, saying that sle had only spoken jokingly, and there was evidence that many employees had joked frequently about slowing down. 244 N.L.R.B. at 597-98.

The steward's beliavior may, liowever, have been part of a continuous inonitoring and regulation by the employees of their co-workers' work-rates. The members of a work group will often work at the same rate by tacit or explicit agreement; if they did not, faster workers would give management extra leverage to mcrease production rates, to the detriment of other workers in the group. J. KuHN, supra note 3, at 133. If there was such a plan at work in Midwest Precision, it is not clear that the steward led or organized it; in its inference that the steward led the slowdown, Member Jenkins's opinion relies on the Board's theory of implicit leadership, see supra notes 2226 and accompanying text.

As the leader of his work group, a steward is caught in a double-bind when the interests of the work group in maintaining a unifonn production rate directly conflict with the interests of 
inguished Precision Castings Co. ${ }^{47}$ and Gould Corp. ${ }^{48}$ by noting that the stewards in those cases neither instigated nor led the production disruptions. ${ }^{49}$ In a footnote to Member Jenkins's opinion, Member Murphy aunbiguously stated that there was no need to either distinguish or to follow Precision Castings or Gould because the steward in Midwest Precision engaged in "improper conduct in direct violation of a contractual clause." 50

In a concurring opinion, Chairman Fanning distimguished Precision Castings and Gould by suggestimg that in those cases an antiunion animus motivated the discriminatory discipline. ${ }^{51}$ Chairman Fanning

management and the union as expressed in the collective bargaining agreement. See, e.g., J. Kuhn, supra note 3, at 119; A. Nash, The Union Steward: Duties, Rights, and STatus 4344 (1977). On the one hand, the steward is a worker and shares his co-workers' interests and concerns, $i d$. at 42 ; in addition, to retain the allegiance of his constituency, he must comply with, or at least not actively thwart, their desires. See J. KuHN, supra note 3, at 106. On the other hand, the steward, as a union representative, must uphold and help implement the terms of the collective bargaining agreement. See D. MILLER \& W. ForM, supra note 23, at 263; A. NASH, supra, at 8-9. These irreconcilable demands place a steward in an impossible situation: the steward in Midwest Precision would fall out of favor with her co-workers if she did not help maintain a uniform work rate and would be fired by her employer if she did. The courts have become increasingly sensitive to this type of predicament. See infra note 142 and accoinpanying text.

47. 233 N.L.R.B. 183 (1977).

48. 237 N.L.R.B. 881 (1978), enforcement denied, 612 F.2d 728 (3d Cir. 1979), cert. denied, 449 U.S. 890 (1980). Gould was the first of the line of NLRB decisions following Precision Castings. Precision Castings characterized as a "fundamental axiom of our national labor pohicy" the proposition that "an individual cannot be discriminated against because [sic] of his union status." 237 N.L.R.B. at 881.

49. Midwest Precision Castings Co., 244 N.L.R.B. 597, 598 (1979).

50. 244 N.L.R.B. at 598 n.7. Member Murphy did not say what constituted the violation; because her opinion is appended in a footnote to Member Jenkins's opinion, she inay have agreed with him that the steward's fault lay in her instigation or leadership of the slowdown.

In Armour-Dial, Inc., 245 N.L.R.B. 959 (1979), enforcement denied, 638 F.2d 51 (8th Cir. 1981), Member Murphy agam explicitly declined to apply Precision Castings and Gould and based the discrimmatory discipline's illegahity on the fact that the disciplined union officials did not participate in the work stoppage. Id. at 961 (Member Murphy, concurring). In Rogate Indus., Inc., 246 N.L.R.B. 898, $899-900$ (1979), Meinber Murphy concurred with Meinbers Penello and Truesdale, putting them in the majority and leaving Chairman Fanning and Member Jenkins to dissent. Agam, Member Murphy explicitly refused to apply Precision Castings and Gould. Instead, she based her opinion of the legality of the discriminatory discipline in Rogate on the union representatives' inore active role in the illegal strike and on the fact that soine of the inore active rank-and-file participants had also been disciplined. $1 d$. Member Murphy never joined Members Penello and Truesdale in their call for the overruling of Precision Castings and Gould, but her extreme reluctance to rely on those decisions, in which she joined, was at best baffling and at worst an indication that the majority position has always stood on shaky if not eroding ground.

51. Midwest Precision, 244 N.L.R.B. at 599 (Chairman Fanning, concurring). The issue of possible antiunion animus is part of the established test for violations of section 8(a)(3), 29 U.S.C. \& 158(a)(3) (1976). See infra note 73 and accompanying text. Nevertheless, it is strange that Chairman Fanning should suggest that this line of analysis determined the outcome in Midwest Precision and Gould. Although there was some evidence of hostihty in these cases, see, e.g., infra note 84 , the Board did not base the section 8(a)(3) violation on those findings. 
also suggested that an employer may predicate discipline upon a union representative's status "to the extent that status colors the impact of her action,"s2 which sounds like a corollary to the supposedly abandoned theory of implicit leadership. ${ }^{53}$ Predictably, Members Penello and Truesdale approved the discriminatory discipline (with Member Penello mvoking the exchange theory and the theory of implicit leadership), found the case to be indistinguishable from Gould, and protested the Board's current position. 54

The composition of the Board has radically changed in the past few years, ${ }^{55}$ and to date, the present Board has decided only one case on point. In Consolidation Coal Co., ${ }^{56}$ the Board reaffirmed its position in Precision Castings and in Gould, ${ }^{57}$ but the stability of this position may be contingent on the continued presence of Members Fanning and Jenkins. ${ }^{58}$ Furthermore, although the majority of the Board reached a consensus that predication of a union representative's duty on his status violates section $8(a)(3)$ of the NLRA, this rule is subject to varymg imterpretations, as Midwest Precision illustrates. Fmally the Board has yet to articulate a clear rule as to the circumstances, if any, under which

52. 244 N.L.R.B. at 599 (Chairman Fanning, concurring).

53. According to Rummage's conservative interpretation of Precision Castings, 233 N.L.R.B. 183 (1977), the Board never rejected the theory of implicit leadership. See supra note 38. This interpretation reconciles Chairman Fanning's opinion with that of Members Jenkins and Murphy. See supra notes 47-50 and accompanying text. See also Rummage, supra note 19, at 277.

54. 244 N.L.R.B. at 600-02 (Meinber Penello, concurring); id. at 602 (Member Truesdale, concurring).

55. Member Murphy left the Board in December, 1979; Meinbers Penello and Truesdale left in January, 1981. The following people constitute the current membership: Chairman Van de Water (arrived August, 1981, on a recess appointment); Member Fanning (term expires December, 1982); Meanber Hunter (arrived August, 1981; term expires in 1985); Member Jenkins (term expires August, 1983); Member Zimmerman (arrived August, 1980; term expires in 1984).

56. 263 N.L.R.B. No. 188 (1982).

57. Id. at 6-8.

58. The terms of both these unembers will soon expire. See supra note 55.

Member Zimunerman concurred with Members Fanning and Jenkins in Consolidation Coal, but Chairman Van de Water and Member Hunter dissented. Chairman Van de Water wrote that "a union official or steward, as a selected union leader, has an affirmative duty to see that employees hive up to their contractual commitments." 263 N.L.R.B. No. 188, at 24 (Chairman Van de Water, dissenting). The Chairman also beheves that "[s]hop stewards are the natural leaders of any work stoppage in which they participate." Id. at 30. Chairman Van de Water is thus the heir to Member Penello's theories of negative and implicit leadership. See supra notes 22-29 and accompanying text. Member Hunter agrees with the Chairman that union representatives have a higher duty than the rank-and-file in the context of an illegal work stoppage. See 263 N.L.R.B. No. 188, at 41, 46, 51-53 (Meunber Hunter, dissenting). According to Member Hunter, union representatives have a duty "to abide by and enforce" the no-strike clause, $i d$ at 46 , and this duty, which is "inherent in a no-strike clause," $i d$, requires affirmative discouragennent of the illegal strike, by word and by example, id. at 54 n.74. Both Chairman Van de Water and Member Hunter would overrule Precision Castings and Gould. 263 N.L.R.B. No. 188 at 24, 33 (Chairman Van de Water, dissenting); id. at 40 n.45 (Member Hunter, dissenting). 
it is permissible for an employer to discipline a union representative more severely in the aftermath of an illegal work stoppage. ${ }^{59}$

\section{Predication of the Representative's Higher Duty on the Collective Bargaining AgreEment}

Several federal courts of appeals have heard cases on the issue of discriminatory discipline in retaliation for a union representative's role m an illegal work stoppage. 60 In their initial (1979) decisions, the Courts of Appeals for the Third and Seventh Circuits presented dual bases for their holdings that the discriminatory discipline did not violate section 8(a)(3) of the NLRA. ${ }^{61}$ First, the courts applied the established test for violations of section 8(a)(3), as articulated in NLRB v. Great Dane Trailers, Inc. ${ }^{62}$ and held that to punish a union representa-

59. Although the NLRB rejected the status-based theory of responsibility, it has never clearly acknowledged that there may be a contractual basis for the union representative's duty to dissuade illegal strikers. In several decisions, the Board explicitly left as an open question whether protection under section 8(a)(3), 29 U.S.C. $\$ 158$ (a)(3) (1976), may be waived by a contractual provision that explicitly requires union representatives to dissuade illegal strikers. See Rogate Indus., Inc., 246 N.L.R.B. 898, 900 (1979) (Chairman Fanning \& Member Jenkims, dissenting); see also Armour-Dial, Inc., 245 N.L.R.B. 959, 960 n.8 (1979), enforcement denied, 638 F.2d 51 (8th Cir. 1981); Pontiac Motors Div., Gen. Motors Corp. 132 N.L.R.B. 413, 415 (1961). On one occasion, the Board held that a contract explicitly requiring union representatives to take certain affirnative dissuasive measures in the event of an illegal work stoppage does not legally validate discriminatory discipline for failure to dissuade. Gould Corp., 237 N.L.R. 881, 881 (1978), enforcement denied, 612 F.2d 728 (3d Cir. 1979), cert. denied, 449 U.S. 890 (1980). But see NLRB v. South Cent. Bell Tel. Co., No. 81-4159, slip op. at 57 (5th Cir. Oct. 4, 1982); Fournelle v. NLRB, 670 F.2d 331, 339 n.16 (D.C. Cir. 1982). Analogously, the Board has also opposed the enforcement of such contractual provisions (or enforcement of the no-strike clause) against einployees by employer discipline. See Hammermill Paper Co., 252 N.L.R.B. 1236, 1237 (1980), enforced, 658 F.2d 155 (3d Cir. 1981), petition for cert. filed, 50 U.S.L.W. 3703 (U.S. Jan. 1, 1982) (No. 81-1438); Brief for Respondent at 10, Hammermill Paper Co. v. NLRB, 658 F.2d 155 (3d Cir. 1981), petition for cert. filed, 50 U.S.L.W. 3703 (U.S. Jan. 1, 1982) (No. 81-1438); see also infra note 152. In the Board's most recent decision on point, Member Fanning exphicitly noted that the propriety of a contractual waiver of section 8(a)(3) protection is still an open question. Consolidation Coal Co., 263 N.L.R.B. No. 188, at 16-17 n.18 (1982); see also id. at 17 n.19. Member Ziminerman, however, wrote in support of such a waiver. Id. at 21 n.23 (Member Zimmerinan, concurring).

For an especially strong argument against the waiver of section 8(a)(3) protection, see Levy, supra note 3, at 720-25. Cf. Barrentine v. Arkansas-Best Freight Sys., Inc., 450 U.S. 728, 740 (1981) (employees' rights under coinpensation statute may not be waived by collective bargaining agreement); Alexander v. Gardner-Denver Co., 415 U.S. 36, $51-52$ (1974) (Title VII rights may not be waived).

60. See NLRB v. South Cent. Bell Tel. Co., No. 81-4159, slip op. (5th Cir. Oct. 4, 1982); Szewczuga v. NLRB, No. 81-1054, slip. op. (D.C. Cir. Aug. 17, 1982); Fournelle v. NLRB, 670 F.2d 331 (D.C. Cir. 1982); Metropolitan Edison Co. v. NLRB, 663 F.2d 478 (3d Cir. 1981), cert. granted, 102 S. Ct. 2926 (1982); Hammernill Paper Co. v. NLRB, 658 F.2d 155 (3d Cir. 1981), petition for eert. filed, 50 U.S.L.W. 3703 (U.S. Jan. 1, 1982) (No. 81-1438); C.H. Heist Corp. v. NLRB, 657 F.2d 178 (7th Cir. 1981); NLRB v. Armour-Dial, Inc., 638 F.2d 51 (8th Cir. 1981); Gould, Inc. v. NLRB, 612 F.2d 728 (3d Cir. 1979), cert. denied, 449 U.S. 890 (1980); Indiana \& Mich. Elec. Co. v. NLRB, 599 F.2d 185 (7th Cir. 1979), cert. denied, 444 U.S. 1014 (1980).

61. 29 U.S.C. $\& 158(a)(3)(1976)$.

62. 388 U.S. 26 (1967). 
tive more harshly than the rank-and-file for his role in an illegal strike is not "inherently destructive" of important employee rights. ${ }^{63}$ Second, the courts held that the more severe punishment was justified by the union representative's breach of his higher duty ${ }^{64}$ as derived from a status-based theory of responsibility. 65

In their more recent (1981) decisions, ${ }^{66}$ the Courts of Appeals for the Third and Seventh Circuits abandoned their explicit reliance on the Great Dane test, and, paralleling the NLRB's earlier shift of analysis, departed from the status-based theory of responsibility. ${ }^{67}$ These courts now look to the collective bargaining agreement as the source of the union representative's duty in the context of an illegal strike. 68

\section{A. The Great Dane Test for Discrimination in Violation of Section $8(a)(3)$.}

The Supreme Court's landmark decision in NLRB v. Great Dane Trailers, Inc. ${ }^{69}$ summarized the Court's earlier section $8(a)(3)$ decisions $^{70}$ and established the basic test for impermissible discrimination ${ }^{71}$.

63. Gould, Inc. v. NLRB, 612 F.2d 728, 733 (3d Cir. 1979), cert. denied, 449 U.S. 890 (1980); Indiana \& Mich. Elec. Co. v. NLRB, 599 F.2d 227, 232 (7th Cir. 1979).

64. Gould, 612 F.2d at 733; Indiana \& Mich. Elec., 599 F.2d at 230-32.

65. Gould, 612 F.2d at 733; Indiana \& Mich. Elec., 599 F.2d at 230-32. Although the Third Circuit in Gould expressly endorsed the status-based theory, $612 \mathrm{~F} .2 \mathrm{~d}$ at 733, it also noted that the union representative in Gould had a contractual duty to dissuade. Id. See infra notes 104-06 and accompanying text.

66. Metropohtan Edison Co. v. NLRB, 663 F.2d 478 (3d Cir. 1981), cert. granted, 102 S. Ct. 2926 (1982); Hammermill Paper Co. v. NLRB, 658 F.2d 155 (3d Cir. 1981), petition for cert. filed, 50 U.S.L.W. 3703 (U.S. Jan. 1, 1982) (No. 81-1438); C.H. Heist Corp. v. NLRB, 657 F.2d 178 (7th Cir. 1981).

67. Metropolitan Edison, 663 F.2d at 481-83; Hammermill Paper, 658 F.2d at 163; Heist, 657 F.2d at 183. The Third Circuit unequivocally renounced its earher rehance on a status-based theory, see infra notes 126-40 and accompanying text, but the position of the Seventh Circuit is more ambiguous, see infra notes 107-25 and accompanying text.

68. Early in 1981, the Eighth Circuit reviewed an NLRB decision involving the discriminatory discipline of union executive committee members for their role in an illegal work stoppage. NLRB v. Armour-Dial, Inc., 638 F.2d 5I (8th Cir. 1981). Armour-Dial antedated the 1981 decisions by the Third and Seventh Circuits and does not reflect their move away from the Great Dane test. Instead, Armour-Dial closely follows the earlier decisions in those circuits.

The most recent cases addressing these issues are: NLRB v. South Cent. Bell Tel. Co., No. 81-4159, ship op. (5th Cir. Oct. 4, 1982); Szewczuga v. NLRB, No. 81-1054, slip op. (D.C. Cir. Aug. 17, 1982); Fournelle v. NLRB, 670 F.2d 331 (D.C. Cir. 1982). Although Fournelle purports to derive the duty to dissuade from the collective bargaining agreement, it implicitly adopts a questionable status-based theory. See infra notes 174-77 and accompanying text. Fournelle, however, must be read in hight of Szewczuga, which clearly supports the contractual theory of responsibility, see infra text accompanying notes 178-80, as does South Central Bell, see infra note 149 and accompanying text.

69. 388 U.S. 26 (1967).

70. These decisions are: American Ship Bldg. Co. v. NLRB, 380 U.S. 300 (1965); NLRB v. Brown, 380 U.S. 278 (1965); NLRB v. Erie Resistor Corp., 373 U.S. 221 (1963).

71. In Great Dane, the Court held that the elements of a section 8(a)(3) violation are "dis- 
against union representatives: discriminatory treatment "capable of discouraging membership in a labor organization"72 or "motivated by an antiumion purpose"73 violates section 8(a)(3). In addition, the Great Dane Court lightened the complainant's burden of proof by creating a presumption of antiunion animus in cases in which the employer's conduct is "so "inherently destructive of employee interests" "74 that it bears " 'its own imdicia of intent'." If destructive, a legitimate business purpose for the discrimination may outweigh its potential harm; ${ }^{76}$ but if the detriment to employee rights is " "comparatively slight," " a business purpose will always outweigh the possible injury unless the complamant explicitly proves an antiunion animus. ${ }^{77}$

The Great Dane test is difficult and confusing to apply, ${ }^{78}$ and the lower courts have been left to determine for themselves the meaning of the phrases "inherently destructive" and "comparatively slight" and to create a standard of weights for the balancing test. ${ }^{79}$ Given a legitimate business justification, the lower courts will generally find a violation of

crimination and a resulting discouragement of union membership." 388 U.S. at 32. See supra note 5 for the text of section $8(a)(3)$.

72. 388 U.S. at 32. "Discouraging membership in a labor organization "includes discouraging participation in concerted activities . . such as a legitimate strike." Id. (quoting NLRB v. Erie Resistor Corp., 373 U.S. 221, 233 (1963)). Presumably, it also includes discouraging participation in any legitinate union activity, such as being a union representative.

To establish a violation of section 8(a)(3), one need not show that employees have actually been discouraged from participation in union activities; the resulting discouragement may be inferred from the nature of the employer's conduct. See Radio Officers' Union v. NLRB, 347 U.S. $17,48-52$ (1954).

73. 388 U.S. at 33 (citing American Ship Bldg. Co. v. NLRB, 380 U.S. 300 (1965)). An antiunion animus taints otherwise lawful conduct. 388 U.S. at 33. For example, discharging an employee for participating in an illegal strike is lawful, but if the discharge is demonstrably motivated by an antiunion animus, it violates section 8(a)(3). See NLRB v. Erie Resistor Corp., 373 U.S. 221, 227 (1963).

74. 388 U.S. at 33 (quoting NLRB v. Brown, 380 U.S. 278, 287 (1965)).

75. 388 U.S. at 33 (quoting NLRB v. Erie Resistor Corp., 373 U.S. 221, 228, 231 (1963)). Such conduct "carries with it "unavoidable consequences which the employer not only foresaw but which he must have intended'. . . " 388 U.S. at 33 (quoting Erie Resistor, 373 U.S. at 228, 231).

76. 388 U.S. at 33.

77. Id. at 34 .

78. See Note, Harsher Discipline for Union Stewards than Rank-and-File for Participation in Illegal Strike Activity, CHI[-]KENT L. REv. 1175, 1177-81 (1980).

79. In NLRB v. Fleetwood Trailer Co., 389 U.S. 375 (1967), the Court clarified somewhat the Great Dane method of analysis: if the employer's discriminatory conduct has or could have a discouraging effect on the exercise of employee rights, there is a prima facie violation of section 8(a)(3), but if the employer shows that his discriminatory conduct had a legitimate business purpose, this may outweigh the adverse effect on employee rights. Id. at 378. Neither Great Dane nor Fleetwood Trailer provide criteria for measuring the degree of harm that the discriminatory conduct might cause. Furthermore, because the companies in Fleetwood Traller and Great Dane presented no business justification at all, the Court was spared the difficulty of determining the degree to which einployee rights had been impaired. Even a slight impairment is impermissible if 
section 8(a)(3) if the potential effect of the discriminatory conduct on protected employee rights is inherently destructive and will generally allow the discrimination if its potential effects are comparatively slight. Although no clear rule distinguishes inherently destructive conduct ${ }^{80}$ from conduct that has a comparatively shght adverse effect, ${ }^{81}$ the courts generally label as inherently destructive any discriminatory conduct that jeopardizes the future exercise of employee rights or penalizes protected activity. ${ }^{82}$

\section{B. The Courts'Application of the Great Dane Test and the Status- Based Theory of Responsibility.}

The Courts of Appeals for the Third and Seventh Circuits closely followed and applied Great Dane in their initial reviews of the NLRB's decisions on the discriminatory discipline of union representatives who participate in an illegal work stoppage. ${ }^{83}$ In neither case was an antiunion animus expressly alleged or proved; 84 rather, the issue turned on

the employer offers no justification whatsoever for its discrimination. Fleetwood Trailer, 389 U.S. at 380; Great Dane, 388 U.S. at 34-35.

80. Discriminatory conduct found to be inherently destructive includes the following: granting vacation benefits only to strikers who returned before the end of a strike, NLRB v. Westinghouse Elec. Corp., 603 F.2d 610, 617 (7th Cir. 1979); assigning returned strikers undesirable work, NLRB v. Moore Business Forms, 574 F.2d 835, 842 (5th Cir. 1978); and guaranteeing superseniority to strikebreakers, NLRB v. Erie Resistor Corp., 373 U.S. 221, 227 (1963).

81. Conduct found to have a comparatively slight effect on enployee rights includes the following: moving an office outside the jurisdiction of the local union, Loomis Courier Serv., Inc. v. NLRB, 595 F.2d 491, 495, 499 (9th Cir. 1979); discharging a union organizer for good cause, Waterbury Community Antenna, Inc. v. NLRB, 587 F.2d 90, 97 (2d Cir. 1978); and giving retroactive pay raises only to those strikers who returned to work by a specific date (where the strike was aimed at obtaining the retroactive raises), Portland Williamette Co. v. NLRB, 534 F.2d 1331, 1334 (9th Cir. 1976).

82. See, e.g., Kansas City Power \& Light Co. v. NLRB, 641 F.2d 553, 559 (8th Cir. 1981); NLRB v. Haberman Constr. Co., 641 F.2d 351, 359 (5th Cir. 1981); Portland Williamette Co. v. NLRB, 534 F.2d 1331, 1334 (9th Cir. 1976).

83. See Gould, Inc. v. NLRB, 612 F.2d 728 (3d Cir. 1979), cert. denied, 449 U.S. 890 (1980); Indiana \& Mich. Elec. Co. v. NLRB, 599 F.2d 227 (7th Cir. 1979). For an analysis of the application of Great Dane in Indiana \& Mich. Elec., see Note, supra note 78, at 1184-92.

The NLRB has not relied heavily on Great Dane in this type of case, although the Board sometimes speaks of "inherently destructive conduct," see, e.g., Indiana \& Mich. Elec. Co., 237 N.L.R.B. 226, 229 (1978), enforcement denied, 599 F.2d 227 (7th Cir. 1979), and the presence or lack of an "antiumion animus," see, e.g., J.P. Wetherby Constr. Corp., 182 N.L.R.B. 690, 697 (1970) (opinion of trial examiner, affirmed by the Board). See also Consolidation Coal Co., 263 N.L.R.B. No. 188, at 41-46 (1982) (Member Hunter, dissenting) (application of Great Dane to validate discrimmatory discipline in the context of an illegal strike).

84. See, e.g., Indiana \& Mich. Elec., 599 F.2d at 230 n.5.

The coinplamant in Gould also alleged a violation of section 8(a)(4), which provides that "[i]t shall be an unfair labor practice for an einployer . . to discharge or otherwise discriminate against an employee because he has filed charges or given testimony under this subchapter." 29 U.S.C. \& 158(a)(4) (1976). The steward in Gould made a practice of filing coinplaints directly with various administrative agencies, bypassing the internal dispute-resolution mechanism set up by the collective bargaining agreenent. Although it was within the steward's rights to pursue this 
whether the employer's conduct was inherently destructive of any important employee rights.

In Indiana \& Michigan Electric Co. v. $N L R B,{ }^{85}$ five union representatives participated in an illegal strike, although three of the representatives later jomed the effort to end the strike. The rank-and-file participants received a written warning from the employer; 86 the representatives who aided in the resolution of the strike received one-day suspensions; and the representatives who stayed out received three-day suspensions. Following Great Dane, the Indiana \& Michigan Electric court recognized that the company's discriminatory conduct might violate section 8(a)(3) despite its valid busmess justification ${ }^{87}$ if it was " 'inherently destructive' of important employee rights." 88 The court ruled, however, that because union representatives have no right to participate in an illegal strike, no impermissible impairment of their rights occurs when an employer disciplines them for their participation. ${ }^{89}$ The court also held that the union representatives had, and breached, a "greater responsibility" than the rank-and-file participants and that this "greater fault" justified their more severe discipline. ${ }^{90}$ Thus, the discriminatory discipline of the union representatives was not inherently destructive of protected rights and did not violate section 8(a)(3).

Soon after the Court of Appeals for the Seventh Circuit decided Indiana \& Michigan Electric, the Court of Appeals for the Third Circuit heard Gould, Inc. v. NLRB.91 In Gould, employee unrest over a

course of action, the company fired the steward at least in part in retaliation for this practice. Gould Corp., 237 N.L.R.B. 881, 881 (1978), enforcement denied, 612 F.2d 728 (3d Cir. 1979), cert. denied, 449 U.S. 890 (1980). This may be the evidence of an antiunion animus to which Chairman Fanning refers in Midwest Precision Castings Co., 244 N.L.R.B. 597 (1979) (Chairman Fanning, concurring). See supra note 51 and accompanying text. The Gould court held that the steward's involvement in the illegal work stoppage warranted his discharge despite the possible violation of section 8(a)(4). 612 F.2d at 734 .

85. 599 F.2d 227 (7th Cir. 1979).

86. Such a warning becomes part of the employee's record and may be the basis for discharge if he is disruptive in the future. See, e.g., Hammermill Paper Co. v. NLRB, 658 F.2d 155, 156 (3d Cir. 1981), petition for cert. filed, 50 U.S.L.W. 3703 (U.S. Jan. 1, 1982) (No. 81-1438).

87. 599 F.2d at $229-30 \&$ nn.4 \& 5. The company's busmess justification was its need to enforce the no-strike clause and deter future violations in order to assure uninterrupted electrical service. Id. at 229-30 n.4.

88. Id. at 229-30.

89. Id. at 230; see infra note 94.

90. Id. at 232; see id. at 230.

91. 612 F.2d 728 (3d Cir. 1979), cert. denied, 449 U.S. 890 (1980). See Note, 49 Geo. WaSH. L. REv. 411 (1981) (discussing Gould).

Six months before the Third Circuit's decision in Gould, the District Court for the Western District of Pennsylvania, closely following the Seventh Circuit's Indiana \& Mich. Elec. opinion, upheld the discriminatory discharge of a union official who participated in an illegal work stop- 
recently filed grievance culminated in a two-hour work stoppage in violation of the no-strike clause of the collective bargaining agreement. The steward who filed the grievance was on his coffee break when the stoppage began, but he refused to return to work or to encourage the other employees to return. The coinpany discharged the steward; he was the only employee pumshed for the illegal work stoppage. In an opinion that extensively quoted Indiana \& Michigan Electric, the Court of Appeals for the Third Circuit followed the Court of Appeals for the Seventh Circuit and held that the discriminatory discipline of a union steward for his participation in an illegal work stoppage did not violate section 8(a)(3) under the Great Dane test. ${ }^{92}$ The court reached its decision without mentioning any business justification for the discriminatory discipline; rather, the court held that the steward had, and breached, a duty "to take positive steps to halt ... [the] work stoppage."93

The Indiana \& Michigan Electric and Gould courts appear to have had dual bases for concluding that the discriminatory discipline of a union representative for his role in an illegal work stoppage does not violate section 8(a)(3) of the NLRA. First, the courts apphed the Great Dane test and held that the discriminatory punishment was not inherently destructive of protected employee rights. Second, the courts held that the union representatives' failure to discharge their higher duty justified the discriminatory punishment and thereby avoided the alleged violation of section 8(a)(3). These dual holdings appear to be alternate bases for the courts' conclusions only because the courts do not articulate the relationship between them. It is the existence of a higher duty for union representatives that prevents the discriminatory punishment from being destructive of protected employee rights.94 To illustrate by analogy, in the absence of a no-strike clause, punishment

page. Liotta v. National Forge Co., 473 F. Supp. 1139 (W.D. Pa. 1979), rev'd in part, aff d in part, 629 F.2d 903 (3d Cir. 1980), cert. denied, 451 U.S. 970 (1981).

92. Gould, 612 F.2d at 733.

93. $I d$.

94. The Indiana \& Michigan Electric court held that the discriminatory discipline had no adverse effect on employee rights because the representative had no right to participate in an illegal strike, 559 F.2d at 230. The Gould court held that the discrimination did not impair the exercise of any legitimate employee right because it only deterred employees who intended to participate in illegal work stoppages from becoming union representatives. 612 F.2d at 733. Each of these holdings is shightly of target. If the effect of the discipline is to discourage representatives from participatimg in illegal strikes, it is not inherently destructive of protected rights-the Indiana \& Michigan Electric court was correct in this respect. The Indiana \& Michigan Electric court, however, ignored the possibility that the threat of discriminatory discipline will discourage employees from becoming union represeutatives, an important and protected prerogative. The Gould court did consider this possibility, but apparently concluded that the threat of discriminatory discipline would deter only employees who had illicit intentions from becoming union representatives; this summary conclusion seems unfounded. 
of striking employees would violate section 8(a)(3) because it would discourage participation in protected, legitimate strikes. ${ }^{95}$ A no-strike clause removes the employees' former right to strike from the "protected" category and justifies punishment of illegal strikers.96 Similarly, if union representatives are legally subject to higher hability than the rank-and-file with regard to illegal strikes, their former right to be treated the same as rank-and-file participants is no longer protected, and discriminatory discipline is justified. This higher hability could derive from the representative's leadership of the strike, ${ }^{97}$ from his breach of an affirmative duty to dissuade the illegal strikers, or from an explicit waiver of his right under section 8(a)(3) not to be punished more severely than the rank-and-file for his participation in the strike. ${ }^{98}$ Once his greater liability is established, the representative has no right to be free of selective discipline, and therefore the discrimination is not inherently destructive of any protected right. Thus, the representative's higher duty is the necessary prerequisite for the satisfaction of the Great Dane test.

As the Court of Appeals for the Seventh Circuit noted in retrospect, the Indiana \& Michigan Electric court "did not define exactly what [the union representative's] 'higher responsibility' is or froin whence it arises." 99 The Indiana \& Michigan Electric court, however, cited with approval several of the NLRB decisions that predicate hability on the union representative's implicit leadership of an illegal strike, ${ }^{100}$ and the court did not inention any affirmative duty to dissuade illegal strikers. Therefore, the Indiana \& Michigan Electric court apparently adopted the theory of implicit leadership previously rejected by the NLRB as an impermissible predication of hability on the union representative's status. ${ }^{101}$

In Gould, Inc. v. NLRB, ${ }^{102}$ the Court of Appeals for the Third Circuit closely followed Indiana \& Michigan Electric, and at first glance

95. See supra note 72.

96. See supra notes 13-14 and accompanying text.

97. See supra note 22.

98. It is an open question whether the umion representatives' right to equal treatment inay be waived. See supra note 59. This section of the note assumes that a waiver can be valid. See Fournelle v. NLRB, 670 F.2d 331, 339 n.16 (D.C. Cir. 1982).

99. C.H. Heist Corp. v. NLRB, 657 F.2d 178, 182 (7th Cir. 1981).

100. See Indiana \& Mich. Elec. Co. v. NLRB, 599 F.2d 227, 230-31 \& n.9 (7th Cir. 1979).

Under the theory of implicit leadership, if a union represeutative participates in an illegal strike, he is deemed to have led it. See supra notes 22-26 and accompanying text. The Board rejected this theory in 1977. See supra notes $38-41$ and accompanying text.

101. 599 F.2d at $230-31 \&$ n.9.

102. 612 F.2d 728 (3d Cir. 1979), cert. denied, 449 U.S. 890 (1980). 
the analyses are indistinguishable. ${ }^{103}$ There is, however, an important factual distinction between Gould and Indiana \& Michigan Electric which renders the Gould opinion highly ambiguous. In addition to the customary no-strike clause, the collective bargaining agreement in Gould clearly and explicitly imposed upon the union and its representatives an affirmative duty to take specific steps to dissuade illegal strikers. ${ }^{104}$ As a result, in the midst of its strong concurrence witl Indiana \& Michigan Electric, the Gould court also held that the union representative was punished more severely than the rank-and-file participants in the illegal strike because he breached his contractual obligation to dissuade them. ${ }^{105}$ This suggests a theory different from the status-based theory of implicit leadership in Indiana \& Michigan Electric: in Gould the union representative's higher responsibility was an affirmative duty to dissuade illegal strikers, derived not from his status but from the explicit terms of the collective bargaining agreennent. ${ }^{106}$ Thus the Gould opimion left unclear which of the two approaclies the Court of Appeals for the Third Circuit would adopt when deciding future discriminatory discipline cases: (1) a status-based tlieory reminiscent of the NLRB's repudiated position, which imposes no affirmative duty on the union representative but exposes him to greater liability than the rank-and-file for participation in an illegal strike; or (2) a contractbased theory of responsibility, which permits harsler discipline of the union representative only if he had, and breached, a contractually imposed duty to dissuade.

103. The Gould court quotes extensively from Indiana \& Michigan Electric and cites with approval the earher NLRB decisions. See id. at $732 \&$ n.4. Gould also appears to endorse the theory of implicit leadership. See id. at 730 n.2.

104. The collective bargaining agreement in Gould required:

In the event of an illegal, unauthorized or uncondoned strike, work stoppage, imterruption or impeding of work, the Local and International Union and its officers shall immediately take positive and evident steps to have those mvolved cease such activity. These steps shall involve the following:

Within not more than twenty-four (24) hours after the occurrence of any such unauthorized action, the Umion, its officcrs and representatives shall publicly disavow same by posting a notice on the bulletin boards throughout the plant. The Union, its officers and representatives shall immediately order its meinbers to return to work, notwithstanding the existence of any wildcat picket line. The Union, its officers and representatives, shall refuse to aid or assist in any way such unauthorized action.

The Union, its officers and representatives, will in good faith, use every reasonable effort to terminate such unauthorized action.

612 F.2d $728,730-31$ n.3.

105. The court held that the umion representative "was disciplined because he participated in an illegal strike and failed to perform his contractual obhgation to take positive steps to halt that work stoppage." Id. at 733 (emphasis added).

106. This theory resembles the theory of negative leadership in that it imposes an additional, affirmative duty on the union representative. See supra notes 27-29 and accompanying text. The theory of negative leadership, however, predicates the duty to dissuade on the representative's status, whereas the analysis suggested in Gould ties it firmly to the explicit terms of the collective bargaining agreement. 


\section{The Merger of the Great Dane Test with the Contract-Based Theory of Responsibility.}

1. The Current Position of the Court of Appeals for the Seventh Circuit. In C.H. Heist Corp. v. NLRB, ${ }^{107}$ the Court of Appeals for the Seventh Circuit cited its earlier decision in Indiana \& Michigan Electric for the proposition that discriminatory discipline is not inherently destructive of employee rights if it is based on a breach of the union representative's higher duty, ${ }^{108}$ but then found that although the union representative in Heist participated in the illegal strike, he discharged his duty as a representative by his efforts to dissuade the illegal strikers. ${ }^{109}$ Therefore, the court concluded that the more severe discipline of the representative impermissibly discriminated against him on the basis of his union status and was inherently destructive of his protected right to hold office. 110

Following the line of analysis suggested by the Court of Appeals for the Third Circuit in Gould, Inc. v. NLRB, ${ }^{111}$ the Heist court looked to the collective bargaining agreement as the source of the union representative's duty. Unlike the agreement in Gould, ${ }^{112}$ the Heist contract

107. 657 F.2d 178 (7th Cir. 1981).

108. Id. at 182 (citing Indiana \& Mich. Elec. Co. v. NLRB, 599 F.2d 227, 230 (7th Cir. 1979)).

109. 657 F.2d at 183. The Heist court attempted to distinguish Indiana \& Michigan Electric on the facts: the representative in Heist tried from the outset to dissuade the illegal strikers, but the representatives in Indiana \& Michigan Electric "did so only belatedly." Id. Yet the facts in Heist were not as clear-cut as the court suggested. In Heist, the company posted new seniority lists that effectively demoted six employees. That night, a group of angry workers went to their steward's hoine. Although he counseled them to use the contractually estabhished grievance procedure to voice their discontent, he had already given then an eniployee list with which to rally their coworkers for a strike. In fact, the workers used the steward's home phone to make the calls. The Heist court was sensitive to the steward's need to retam his "credibihity and the ability . . . to mediate a resolution of the strike," and to refram from taking steps which "would have been suicidal to his union stewardship." Id. at 182. See infra note 142 and accounpanying text. It is not clear, however, that the steward's legitimate desire to retain the workers' allegiance required him to furnish them with the means of organizing an illegal strike. These facts blur the Seventh Circuit's distinction between Heist and Indiana \& Michigan Electric. In both cases the union representatives participated in an illegal work stoppage, and in both cases they made efforts to dissuade the rank-and-file. In each case, these efforts were questionable: the dissuasion in Indiana \& Michigan Electric was belated, and the dissuasion in Heist was accompanied by assistance in organizing the illegal strike.

110. Id. at 183. The Heist court also distinguished Indiana \& Michigan Electric by noting that "[w]e emphasize the inherently less destructive suspensions in Indiana \& Michigan Electric Co. from the discharge in the present case." Id. at $182 \mathrm{n.3}$ (enphasis in original). This distinction is not helpful: 'if the discriminatory punishment might discourage enployees from becoming union representatives, it is immaterial whether the adverse effect is caused by the threat of suspension or the threat of discharge. Perhaps the court meant that a more severe pumishment is more discouraging. The magnitude of the discouragement, however, is irrelevant unless the employer offers a business justification for the discriminatory conduct. See supra note 79.

111. 612 F.2d 728 (3d Cir. 1979), cert. denied, 449 U.S. 890 (1980).

112. See supra note 104 and accompanying text. 
did not impose on union representatives an affirmative duty to dissuade illegal strikers. Instead, the agreement contained a no-strike clause and a clause that required union stewards to ensure enployee compliance with the eollective bargaining agreement (a "compliance clause"). ${ }^{113}$ The Heist court found that this was a "tenuous" basis on which to predicate a higher responsibility for union stewards and concluded that "[i]n the absence of a clear contractual provision requiring [the steward] . . . to cross the [illegal] picket line, his efforts [at dissuasion] were sufficient, if not the most effective possible, to satisfy his obligation to see that the no-strike clause was complied with."114

In Heist, the Great Dane test begins to merge into a contract-based theory of responsibility; discriminatory discipline is permissible under section $8(a)(3)$ of the NLRA ${ }^{115}$ only if the union representative has breached his contractually determined duty. This merger does no harm to the theory behind Great Dane; rather, it facilitates its application. The purpose of the Great Dane presuniption that certain " "inherently destructive" "116 conduct carries " "its own indicia of [anti-uinion] intent" "117 is to relieve the disciplined representative and his union of the heavy burden of proving that the einployer's conduct was motivated by an antiunion animus. In the context of an illegal work stoppage, this purpose is best served by the presumption that if the union representative has discharged his duty under the collective bargaining agreement, an employer's discriminatory punishinent of a representative carries all the "indicia of intent" necessary to establish a violation of section 8(a)(3).

In Heist, the Court of Appeals for the Seventh Circuit appeared to slip effortlessly from its status-based theory of implicit leadership in Indiana \& Michigan Electric Co. v. $N L R B^{118}$ to the contract-based theory suggested by the Court of Appeals for the Third Circuit in Gould,

113. The collective bargaining agreement in Heist provided that "The steward's duties shall consist of seeing that all terms and conditions of the Agreement are being complied with. . . . There shall be no strike or lockout, slowdown, interference, or work interruption on any job." 657 F.2d at 181 .

114. $657 \mathrm{~F} .2 \mathrm{~d}$ at 183. It is arguable that the no-strike clause required the steward (and all other employees) to cross an illegal picket line, that is, to refuse to participate in an illegal work stoppage. No doubt what the court means here is that in the absence of a provision requiring union representatives to take specific affirmative steps in the event of an illegal strike, reasonable and timely efforts to dissuade suffice to satisfy the compliance clause.

115. 29 U.S.C. $\$ 158(a)(3)$ (1976).

116. NLRB v. Great Dane Trailers, Inc., 388 U.S. 26, 33 (1967) (quoting NLRB v. Brown, 380 U.S. 278, 287 (1965)).

117. 388 U.S. at 33 (quoting NLRB v. Erie Resistor Corp., 373 U.S. 221, 228, 231 (1963)).

118. 599 F.2d 227 (7th Cir. 1979). See supra notes 100-01 and accompanying text. 
Inc. v. $N L R B .{ }^{119}$ Actually, the transition was qualified and incoinplete; Heist does not overrule Indiana \& Michigan Electric or repudiate its status-based theory. Rather, it acknowledges the theory of implicit leadership ${ }^{120}$ and creates an exception to it: leadership of an illegal strike may not be inferred from a representative's participation in the strike if he tried from the outset to dissuade the strikers. ${ }^{121}$ The Heist court looked to the terms of the collective bargaining agreement to determine the union representative's duty and the legality of his discriminatory discipline, but the agreement in Heist did not impose an affirmative duty to dissuade. ${ }^{122}$ The Heist court did not find that the union representative had an affirmative duty to dissuade. Rather the court stated that the representative's efforts at dissuasion discharged liis duty under the compliance clause. ${ }^{123}$ If a representative participates im an illegal work stoppage and does not try to dissuade the rank-and-file, he may still, perhaps, be punished under the Indiana \& Michigan Electric/Heist rule as the implicit leader of the strike, regardless of the terms of the collective bargaining agreement. Thus Heist resembles Gould in its ambiguity:124 it is equally compatible with the statusbased theory of implicit leadership and witl the theory of contractual responsibility. 125

119. 612 F.2d 728 (3d Cir. 1979), cert. denied, 449 U.S. 890 (1980). See supra notes 104-06 and accompanying text.

120. Id. at 732-33 (citing Indiana \& Mich. Elec. Co. v. NLRB, 599 F.2d 227, 231 n.9 (8th Cir. 1979)).

121. Heist, 657 F.2d at 183.

122. Heist suggests that the duty to dissuade might be inferred from the conjunction of a nostrike clause and a comphance clause. See supra note 113 and accompanying text. In Carbon Fuel Co. v. UMW, 444 U.S. 212 (1979), the Supreme Court held that it is impermissible to infer from an arbitration clause, which imphies a no-strike clause, see supra note 13, or from a clause that requires the union to "maintain the imtegrity" of the collective bargaining agreement, that an imternational union has an affirmative duty to try to prevent or terminate a local's unauthorized wildcat strike, 444 U.S. at 216, even though the international and the company could have contracted to impose the affirmative duty. Id. at 220-21. Carbon Fuel does not address the question of a union representative's duty with regard to an illegal strike, but it suggests by analogy that an affirmative duty to dissuade may not be inferred from a no-strike clause or from a no-strike clause coupled with a compliance clause, although the duty may be imposed by an explicit contractual provision. See Levy, supra note 3, at 714 \& n.296.

123. Heist, 657 F.2d at 183.

124. See supra notes $103-06$ and accompanying text.

125. Less than three weeks after its decision in Heist, the Seventh Circuit issued its opmion in Caterpillar Tractor Co. v. NLRB, 658 F.2d 1242 (7th Cir. 1981). The Caterpillar court held that Indiana \& Michigan Electric controlled the discriminatory discipline question. Id. at 1248. In Caterpillar, union status, with its "mcumbent responsibilities to avert and discourage wildcat activities," id. at 1245, was one of four criteria for the representatives' dismissal.

Caterpillar is of little precedential value. The court disposes of the discriminatory discipline question in one paragraph and with no mention of Heist, following Indiana \& Michigan Electric as though Heist had never been decided. (This is especially peculiar because one member of the 
2. The Current Position of the Court of Appeals for the Third Circuit. Unlike the Court of Appeals for the Seventh Circuit, the Court of Appeals for the Third Circuit moved definitively away from the statusbased theory of responsibility after its initial, ambiguous decision in Gould. In Hammermill Paper Co. v. $N L R B,{ }^{126}$ a decision independent of but contemporaneous with the decision of the Court of Appeals for the Seventh Circuit im Heist, the Court of Appeals for the Third Circuit invoked the Great Dane test and held that discriminatory discipline based solely on a union representative's status might discourage employees from seeking union office and is therefore inherently destructive of employee rights. ${ }^{127}$ The Hammermill court found no legitimate business justification for the discriminatory discipline because the collective bargaining agreement did not require that union representatives take affirmative steps to dissuade illegal strikers, ${ }^{128}$ a fact that distimguished the Hammermill contract from the one in Gould.129

Unlike the Court of Appeals for the Seventh Circuit in Heist, the Court of Appeals for the Third Circuit in Hammermill did not hesitate to repudiate Indiana \& Michigan Electric Co. v. NLRB. ${ }^{130}$ The Hammermill court pointed out that because the collective bargaining agree1nent in Indiana \& Michigan Electric barely suggested that stewards have any duty in regard to illegal work stoppages, ${ }^{131}$ Indiana $\&$ Michigan Electric im effect held that employers may "smgle out for harsher pumshment union officials who merely participate in illegal strikes regardless of the language in their collective bargaining agreements."'132 The Court of Appeals for the Third Circuit explicitly acknowledged

Caterpillar panel also heard Heist.) Strangely, the Board's motions for rehearing and for rehearing en banc were denied. See id. at 1242.

126. 658 F.2d 155 (3d Cir. 1981), petition for cert. filed, 50 U.S.L.W. 3703 (U.S. Jan. 1, 1982) (No. 81-1438).

127. 658 F.2d at 163 .

128. Id. Contrast the holding of the Seventh Circuit in Indiana \& Mich. Elec. Co. v. NLRB, 599 F.2d 227, 229 n.4 (7th Cir. 1979), that an einployer's need to enforce the no-strike clause is a legitinate business justification for the discriminatory discipline of union representatives.

129. 658 F.2d at 163. For the text of the contractual provision in Gould, see supra note 104.

130. 599 F.2d 227 (7th Cir. 1979).

131. The collective bargaining agreement in Indiana \& Michigan Electric provided:

[T] he International Brotherhood of Electrical Workers and the Local Union agree that the employees covered by this Agreement, or any of them will not be called upon or permitted to cease or abstain from the contmuous performance of the duties pertaining to the positions held by thein with the Company in accord with the terms of this agreement.

Id. at 228 .

In C.H. Heist Corp. v. NLRB, 657 F.2d 178 (7th Cir. 1981), the Seventh Circuit recognized that this provision in the Indiana \& Michigan Electric contract was a questionable basis for inposing a higher duty, $i d$. at 182 , yet it seened willing to infer a duty to dissuade from the "even more tenuous" language of the Heist contract, id., or to predicate that duty on the representative's status. See supra notes $112-14,122-25$ and accompanying text.

132. Hammermill, 658 F.2d at 164. 
that the Indiana \& Michigan Electric rule impermissibly predicates a higher duty, and a correspondingly greater hability, on the union representative's status. ${ }^{133}$ The Hammermill court's rejection of the Indiana \& Michigan Electric rule nakes clear the decision of the Court of Appeals for the Third Circuit to find a violation of section $8(a)(3)^{134}$ unless the discriminatory discipline of a union representative for his role in an illegal work stoppage is predicated on the specific terms of the collective bargaining agreeinent. ${ }^{135}$

A few months after the Hammermill decision, the Court of Appeals for the Third Circuit in Metropolitan Edison Co. v. $N L R B^{136}$ confirmed its determination to evaluate the discriminatory discipline of a union representative in liglit of the collective bargaining agreement. On the facts of Metropolitan, ${ }^{137}$ the Court of Appeals for the Third Circuit had several options: (1) it could follow the Court of Appeals for the Seventh Circuit in Heist and hold that the twenty-five day suspensions in Metropolitan were less destructive of employee rights than the discharges in Heist and Gould and the five-1nonth suspension in Hammermill; ${ }^{138}$ (2) it could limit its holding in Hammermill to the factual pecuharities of that case; 139 or (3) it could confirm its repudiation of Indiana \& Michigan Electric and examine the union representative's duties under the collective bargaining agreeinent. The court chose the third alternative, unequivocally statimg that "[i]f the collective bargaining agreement does not specify that union officials have some responsibility to try to end an illegal work stoppage, then the company inay not

133. Id.

134. 29 U.S.C. $§ 158(a)(3)$ (1976).

135. In Hammermill, the Third Circuit went much further than necessary, given the facts of the case. When the work stoppage occurred, the disciplined steward was working as an employee with a maintenance crew other than the crew for which he was steward. This crew had its own steward, who was also present when the crew illegally stopped work. The court could have found that the steward who suffered the discrimmatory discipline was, under the circumstances of the case, not a steward, but a rank-and-file member of the crew. See 658 F.2d at 167 (Higginbothain, J., concurring). As such, le would have no higher responsibility than other inembers of the crew, and there could be no legitimate reason to punish him more severely. Thus the court could have found a violation of section 8(a)(3) without criticizing Indiana \& Michigan Electric, the case on which it so heavily rehed im Gould. Instead, the court declined to follow the status-bascd theory of Indiana \& Michigan Electric and tied its decision in Gould to the terms of the collcctive bargaining agreement.

136. 663 F.2d 478 (3d Cir. 1981), cert. granted, 102 S.Ct. 2926 (1982).

137. The facts of Metropolitan closely resemble those in Indiana \& Michigan Electric. In both Indiana \& Michigan Electric and Metropolitan, the employer was a public utility, and the collcctive bargaining agreements contamed no-strike clauses; therefore, the busmess justification for the disciplinary action so heavily relied on in Indiana \& Michigan Electric, see supra note 87, was available to the employer in Metropolitan.

138. See supra note 110.

139. See supra note 135. 
impose any greater discipline on union officials than on other participants in the strike." 140

The court also qualified its earlier holding in Gould. Gould concluded that it is permissible to discourage employees who intend to participate in illegal strikes froin becoming union officials; ${ }^{141}$ Metropolitan underscored "the limits of that rationale" and held that it is impermissible to allow the discriminatory discipline of union representatives to "deter others from seeking union office because of the fear that, if an illegal strike were to occur, they would be put into an untenable position: either obey the coinpany and lose their authority, or follow their own judgment and risk harsher punishment."142 The Metropolitan court did not rely on the Great Dane test, which was thus nierged conipletely into the contract-based theory of responsibility. ${ }^{143}$

\section{The Virtues of the Contract-Based Theory of Responsibility.}

As the court in Hammermill Paper Co. v. $N L R B^{144}$ pointed out, the theory of implicit leadership impermissibly predicates liability on the union representative's status. ${ }^{145}$ Therefore, discriminatory discipline in the absence of an affirmative contractual duty to dissuade, or without some exphcit contractual waiver of the representative's right to be protected froin discriminatory discipline, is inherently destructive of protected rights. The contract-based theory of responsibility niakes the "inherently destructive" test for violations of section 8(a)(3) of the NLRA, ${ }^{146}$ as articulated in NLRB v. Great Dane Trailers, Inc., ${ }^{147}$ less obscure and easier to apply in the context of the discriminatory discipline of a union representative for his role in an illegal work stoppage. The contractual analysis of a representative's duty provides a simple general rule by which courts may determine the extent of the representative's responsibility and hability: only if the collective bargaining agreement specifies that the union representative has an affirmative duty to dissuade illegal strikers is he liable for any breach of that duty; if it does not, no liability accrues. The clarity and strictness of the rule also provide clear-cut guidance for a union representative in the vola-

140. Metropolitan, 663 F.2d at 482.

141. 612 F.2d at 733. See supra note 94 .

142. 663 F.2d at 482 (footnote omitted). Both the Third and the Seventh Circuits have shown an increasing awareness of the union representative's precarious position during an illegal work stoppage. Compare id. with Heist, 657 F.2d at 183 (union representative not required to take steps which would be "suicidal" to his union stewardship and to his efficacy as representative).

143. See supra text accompanying notes 115-17.

144. 658 F.2d 155 (3d Cir. 1981).

145. See supra notes $130-32$ and accompanying text.

146. 29 U.S.C. $\& 158(a)(3)(1976)$.

147. 388 U.S. 26 (1967). 
tile and tension-ridden circumstances that surround most illegal strikes. 148 Furthermore, to the extent that the union representative's duty remams uncertain and ill-defined, the einployer retains the power unilaterally to create and enforce the representative's higher responsibility. Because important rights are at stake, any imposition of higher hability ought to be the subject of negotiation between the umion and the employer and ought not occur in the absence of an explicit provision in the collective bargaining agreenent.

\section{Unresolved Problems: The Return of Status-Based Liability Through the ARBITRator's CONSTRUCTION of the Collective BargainING AgreEMENT}

A comparison of the 1979 and 1981 cases that address the issue of discriminatory discipline of umon representatives who participate in illegal work stoppages shows a clear trend in the Courts of Appeals for the Third and Seventh Circuits away froin a status-based theory of higher hability for participation and toward a contract-based theory that imposes liability only if the representative breaches an affirmative and exphicit contractual duty to dissuade. The Court of Appeals for the Fifth $^{149}$ and District of Columbia ${ }^{150}$ Circuits have recently joined this trend. This welcome resolution of the probleins inherent in the statusbased theories, however, is not without difficulties of its own. As a 1982 case, Fournelle v. $N L R B,{ }^{151}$ deinonstrates, status-based liabihity can be resurrected in the guise of a contractual analysis. ${ }^{152}$

148. See Consolidation Coal Co., 263 N.L.R.B. No. 188, at 20 (1982) (Member Zimmerman, concurring) (representatives are entitled to "notice" of their duty and potential liability).

149. See NLRB v. South Cent. Bell Tel. Co., No. 81-4159, slip op. at 60 (5tl Cir. Oct. 4, 1982) (discriminatory discipline "must be based on clear and specific contractual language").

150. See Szewczuga v. NLRB, No. 81-1054, slip op. at 23 (D.C. Cir. Aug. 17, 1982). For a discussion of Szewczuga, see infra notes 178-81 and accoinpanying text.

151. 670 F.2d 331 (D.C. Cir. 1982). For additional criticism of Fournelle, see Levy, supra note 3 , at 718-19.

152. Of course, there are many other unresolved and perplexing issues that pertain to the meclranics of applying the contract-based theory of responsibility. For example, there is a significant problem in determining what actions by a union representative are sufficient to discharge the duty to dissuade once it is contractually imposed. One Board member lias suggested that representatives be held to a "reasonable man" standard of behavior. See Consolidation Coal Co., 263 N.L.R.B. No. 188, at 54 n.74 (1982) (Member Hunter, dissenting). In their most recent decisions, however, the Third and Seventh Circuits lrave been sensitive to the precariousness of the union representative's position during an illegal strike. See supra note 142 and accompanying text. Both courts of appeals agree that the representative need only take the steps explicitly required by the collective bargaining agreement; otherwise, he would lose his authority and credibility in the cyes of the rank-and-file and so become useless as a mediator. See Metropolitan Edison Co. v. NLRB, 663 F.2d 478, 481-82 (3d Cir. 1981), cert. granted, 102 S. Ct. 2926 (1982); C.H. Heist Corp. v. NLRB, 657 F.2d 178, 182-83 (7th Cir. 1981). The Third Circuit, however, noted an exception to its liberal rule, and held that if a union representative does not discharge his duty to dissuade in 
Congress has long favored arbitration as a means of dispute resolution, ${ }^{153}$ and the Supreme Court gave judicial effect to this legislative policy in the Steelworkers Trilogy 154 when it mandated extrene deference to arbitrators' decisions. ${ }^{155}$ The policy of the NLRB with regard

good faith, he is hable to greater punishment. Metropolitan, 663 F.2d at 481 . Courts have long recognized the possibility of covert instigation of illegal strikes by union representatives. See Complete Auto Transit, Inc. v. Reis, 451 U.S. 401,418 n.1 (1981) (Powell, J., concurring in part \& in the judgment); NLRB v. Armour-Dial, Inc., 638 F.2d 51, 56 (8th Cir. 1981); Lewis v. Benedict Coal Corp., 259 F.2d 346, 352 (6th Cir. 1958); United States v. UMW, 77 F. Supp. 563, 566 (D.D.C. 1948), affd in part, appeal dismissed in part, 177 F.2d 29 (D.C. Cir.), cert denied, 338 U.S. 871 (1949). The Third Circuit was therefore correct to acknowledge the possibility of bad-faith dissuasion, a graphic example of which appears in J. KuHN, supra note 3, at 108. Cf. Note, 86 HARV. L. Rev. 447, 457 (1972) (evidentiary problem of identifying tacit support of union for wildcat strike). The difficulty of distinguishing between sincere and insincere dissuasion has led Chairman Van de Water to infer hability from participation, see Consolidation Coal Co., 263 N.L.R.B. No. 188, at 29-30 (1982) (Chairman Van de Water, dissenting), in an arguinent that Members Fanning and Jenkins repudiate as "curbstone psychoanalysis," 236 N.L.R.B. No. 188, at 2 n.2.

Difficult issues largely unaddressed by the courts also surround the presupposition that it is the enployer and not the union that should have the power to punish union representatives who breach an affirmative contractual duty to dissuade. The NLRB has argued that "the einployer's use of job discrimination [i.e., discriminatory discipline] to police stewards' performance as union representatives misuses the einployer-employee relationship [and] intrudes into internal union affairs." Brief for Respondent at 10, Hammermill Paper Co. v. NLRB, 658 F.2d 155 (3d Cir. 1981), petition for cert. filed, 50 U.S.L.W. 3703 (U.S. Jan. 1, 1982) (No. 8I-1438); see Metropolitan Edison Co., 252 N.L.R.B. 1030, 1035 (1980) (opmion of administrative judge, affirmed by Board), enforced, 663 F.2d 478 (3d Cir. 1981), cert. granted, 102 S. Ct. 2926 (1982); Hammermill Paper Co., 252 N.L.R.B. 1236, 1237 (1980), enforced, 658 F.2d 155 (3d Cir. 1981), petition for cert. filed, 50 U.S.L.W. 3703 (U.S. Jan. 1, 1982) (No. 81-1438); Gould Corp., 237 N.L.R.B. 881, 881 (1978), enforced, 612 F.2d 728 (3d Cir. 1979), cert. denied, 449 U.S. 890 (1980). As the administrative judge noted in Metropolitan, the union has no equivalent power to punish inanagement representatives who breach their responsibilities under the collective bargaining agreement, but can only grieve the breach pursuant to the arbitration clause of the agreenient. 252 N.L.R.B. at 1035. A commentator has also argued persuasively against enforcement by the employer of a contractual duty to dissuade, which the representative arguably owes to the union, not to the eniployer. See Levy, supra note 3, at 715, 724-26.

153. In 1947, Congress passed the Taft-Hartley Act, ch. 120, tit. II, 61 Stat. 136 (1947) (codified as amended in scattered sections of 18, 29 U.S.C. (1976 \& Supp. IV 1980)). Sections 201(c) and 203(d) of the Act make it clear that a peaceful, contractual dispute-resolution mechanisin is the preferred means of settling grievances. 29 U.S.C. $\$ \S 171$ (c), 173(d) (1976).

154. United Steelworkers v. American Mfg. Co., 363 U.S. 564 (1960); United Steelworkers v. Warrior \& Gulf Navigation Co., 363 U.S. 574 (1960); United Steelworkers v. Enterprise Wheel \& Car Corp., 363 U.S. 593 (1960).

155. For example, the Court in United Steelworkers v. Enterprise Wheel \& Car Corp. held that because the parties bargamed for the arbitrator's construction of the collective bargaining agreement, courts may not overrule that construction just because their interpretation of the contract would differ. 363 U.S. 593, 599. It has been pointed out, however, that the central issue in the Steelworkers Trilogy was not the NLRB's deference to arbitral awards, but the power of the federal courts to require that arbitration take place. See NLRB v. Pincus Bros., Inc.-Maxwell, 620 F.2d 367, 390 (3d Cir. 1980) (Gibbons, J., dissenting). Furthermore, the Steelworkers Trilogy dealt with the relationship of the courts, not the Board, to the arbitral process, NLRB v. South Cent. Bell Tel. Co., No. 81-4159, ship op. at 54 (5th Cir. Oct. 4, 1982), and the Board's attitude towards arbitral awards may be less deferential than that of the courts because the Board has a congres- 
to deference to arbitral awards has fluctuated wildly, ${ }^{156}$ and there is particular confusion in cases in which an award falls into the broad area of alleged injurics to workers' individual rights, over which arbitrators and the NLRB often have concurrent jurisdiction. ${ }^{157}$ The Board long ago announced a standard for deference to arbitral awards. ${ }^{158}$ Application of this standard, however, requircs the Board to

sional mandate to implement national labor policy, NLRB v. Acme lndus. Co., 385 U.S. 432, 43637 (1967).

The Supreme Court's recent decision in Barrentime v. Arkansas-Best Freight Sys., Inc., 450 U.S. 728 (1981), further delineates the deference which should be afforded arbitral awards. In Barrentine, the Court held that an employee may sue in federal court under the Fair Labor Standards Act even after his wage claim was denied by a joint grievance committee established pursuant to the collective bargaining agreement. The Court noted the "tension" between " $[t]$ wo aspects of national labor policy:" on the one hand, labor and management are encouraged to use the collective bargaining process, including arbitration, as a means of voluntary dispute resolution; on the other hand, the statutory guarantees that protect substantive employee rights inust be enforced. Id. at 734. The Court concluded that "[w]hile courts should defer to an arbitral decision where the employee's claim is based on rights arising out of the collective-bargaining agreement, different considerations apply where the employee's claim is based on rights arising out of a statute designed to provide ininimum substantive guarantees to individual workers." Id. at 737. The Court also noted that arbitral awards inay not adequately protect statutory rights; arbitrators may "lack the competence" to decide complex statutory questions, $i d$. at 743, because "arbitral procedures [are] less protective of individual statutory rights than are judicial procedures," $i d$. at 744 , which also can only afford limited relief, $i d$. at 745 . See also Alexander v. Gardner-Denver Co., 415 U.S. 36, 56-58 (1974).

Despite its sweeping criticism of arbitral awards, Barrentine does not necessarily imply that no deference is due when an arbitrator decides a statutory issue. The Barrentine Court noted that the rights at stake were individual rights, and not rights that accrue on the basis of union status. 450 U.S. at 745. See also Alexander, 415 U.S. at 49-50. Arguably, these latter rights may be fully adjudicated by arbitrators because they pertain to the systen of collective represcntation, even where they also have a statutory basis. The right of employees under section 8(a)(3) of the NLRA, 29 U.S.C. $\$ 158(\mathrm{a})(3)$ (1976), to be free of discriminatory discipline on the basis of their union status, may be exactly the sort of right that would fall outside the Barrentine doctrine, see 450 U.S. at 749-50, 752 (Burger, C.J., dissenting), or it may be construed as an individual liberty that Barrentine protects. In the latter case, the courts (and presunably the Board) decide on a case by case basis to what extent an arbitral award deserves deference. See Alexander, 415 U.S. at 60 n.21 (1974); Consohdation Coal Co. v. Marshall, 663 F.2d 1211, 1218 (3d Cir. 1981).

156. See infra note 160 and accompanying text.

157. Although the exact scope of the arbitrator's jurisdiction is specified in the particular arbitration clause, see $\mathrm{R}$. GORMAN, supra note 5 , at 586 , the general provimce of the arbitrator's expertise is the construction of the collective bargaining agreement. United Steelworkers v. Enterprise Wheel \& Car Corp., 363 U.S. 593, 597 (1960). Strictly speaking, he may not construe labor statutes or make cominon law, but he may consider the contract as incorporating labor statutes, $i d$. at 597-98, and "industrial common law" (also termed the "comnon law of the shop"). United Steelworkers v. Warrior \& Gulf Navigation Co., 363 U.S. 574, 581-82 (1960).

Unfortunately, there is often no neat division between contractual grievances and unfair labor practices (statutory violations within the jurisdiction of the NLRB). See Note, The NLRB and Deference to Arbitration, 77 Y ALE L.J. 1191, 1191 \& nn.6-7 (1968).

158. In Spielberg Mfg. Co., 112 N.L.R.B. 1080 (1955), the NLRB ruled that it would defer to the arbitrator's decision of the statutory issue if the arbitral proceedings were fair, if the parties agreed to be bound by the result, and if the award was not "clearly repugnant to the purposes and policies" of the NLRA. Id. at 1082; see also International Harvester Co., 138 N.L.R.B. 923,929 
determine whether an award is "clearly repugnant"159 to the NLRA, and the Board's repugnancy threshold has progressively lowered with respect to awards that reach statutory issues, such as alleged violations of section $8(a)(3)$ of the NLRA. ${ }^{160}$ In addition, courts must decide by

(1962), affd sub nom. Ramsey v. NLRB, 327 F.2d 784 (7th Cir.), cert. denied, 377 U.S. 1003 (1964) (Board will defer unless arbitral award "palpably wrong").

There is also a fourth, but highly controversial, criterion for the Board's deferral decision. In Monsanto Chem. Co., 130 N.L.R.B. 1097, 1099 (1961), the Board ruled that it would not defer to an arbitrator's award if the arbitrator did not reach the statutory issue upon which the alleged unfair labor practice was based. Thirteen years later, the Board rejected this rule on the grounds that it encouraged multiple litigation of the same factual complaint. Electronic Reproduction Serv. Corp., 213 N.L.R.B. 758, 761-62 (1974). Within a few years, however, this new position showed signs of erosion. See Max Factor \& Co., 239 N.L.R.B. 804, 804 (1978) (Chairman Fanning and Members Murphy and Jenkins held the arbitral award repugnant to statutory policy under Spielberg because the arbitrator failed to reach the statutory issue), enforced, 640 F.2d 197 (9th Cir. 1980), cert. denied, 451 U.S. 983 (1981); Mason and Dixon Limes, Inc., 237 N.L.R.B. 6 (1978) (Member Jenkins joimed Member Murphy in disavowing Electronic Reproduction, id. at 6 n.2); Kansas City Star Co., 236 N.L.R.B. 866 (1978) (Member Murplyy repudiated Electronic Reproduction, id. at $867 \mathrm{n} .1$, while Chairman Fanning and Member Jenkins stated in dissent that Spielberg is applicable only where the contract issue and the unfair labor practice issue are "congruent," id. at $871 \mathrm{n.25)}$. Electronic Reproduction was finally overruled in Suburban Motor Freight, Inc., 247 N.L.R.B. 146, 146 (1980), and the prior rule of Monsanto Chemical was reinstated. During this period of confusion, courts continued to apply Monsanto Chemical's fourtli criterion. See, e.g., Stephenson v. NLRB, 550 F.2d 535, 537-38 (9th Cir. 1977).

Very recently, there lave been signs that the change in the conposition of the Board may result in still more changes in the deferral doctrine. In Professional Porter \& Window Cleaning Co., 263 N.L.R.B. No. 34 (1982), Members Fanning, Jenkins, and Zimmerman reaffirmed Suburban, id. at 6, but in his dissent, Chairman Van de Water unequivocally rejected Suburban, and also argued that the Spielberg repugnancy criterion be narrowly construed to maximize deferral. Id. at 26-27 (Chairnan Van de Water, dissenting). Member Hunter took a middle ground $\mathrm{i} 1 \mathrm{his}$ separate dissent. He would not reject Suburban "out-of-hand," id. at 33, but would defer if the contractual issue is "factually parallel" to the unfair labor practice question and the relevant facts were presented to the arbitrator, $i d$ at 31 . Member Hunter would not require the arbitrator to follow Board precedent, id. at 33, 36, so long as his award is not repugnant to the NLRA, id. at 35 n.32. See also Wolff \& Muries, Inc., 262 N.L.R.B. No. 45 (1982) (Member Hunter "will not defer to a grievance award that indicates on its face that statutory protections have . . [ [not] been considered." Id. at 1-2 n.1). Compare Consolidation Coal Co., 263 N.L.R.B. No. 188, at 4-5 n.7 (1982) with id. at 24 (Chairman Van de Water, dissenting) and id. at 37-38 (Mennber Hunter, dissenting).

The debate over the fourth criterion for deferral becomes even less clear when decisionmakers use different standards to determine whether an arbitrator has in fact reached the statutory issue. Compare NLRB v. Motor Convoy, Inc., 673 F.2d 734, 736 (4th Cir. 1982) (arbitrator who ruled only on question of "just cause" for dismissal under the collective bargaining agreement held to have reached statutory issue under section $8(a)(3)$ because the agreement also provided that employees could not be fired for union activities) with NLRB v. General Warehonse Corp., 643 F.2d 965, 970 (3d Cir. 1981) (arbitrator who ruled only on question of "just cause" for dismissal did not reach statutory issue).

159. Spielberg Mfg. Co., 112 N.L.R.B. 1080, 1082 (1955).

160. Compare National Radio Co., 198 N.L.R.B. 527 (1972) with Suburban Motor Freight, Inc. 247 N.L.R.B. 146 (1980) and General Am. Transp. Corp., 228 N.L.R.B. 808 (1977). See also Consolidation Coal Co., 263 N.L.R.B. No. 188, at $3 \&$ n.5 (1982). But see id. at 38 n.37 (Member Hunter, dissenting). See generally, NLRB v. Pincus Bros., Inc.-Maxwell, 620 F.2d 367, 391-94 (3d Cir. 1980) (Gibbons, J., dissenting); Note, supra note 157 at 1191. 
what standard of review they should evaluate the Board's decision to defer or not to defer to an arbitral award, ${ }^{161}$ and whether they will be guided by the letter of the Board's self-imposed standard for deference or by the liberal spirit in which the Board itself sometimes applies that standard. 162

If the legality of the discriminatory discipline of a union representative under section 8(a)(3) of the NLRA ${ }^{163}$ for his participation in an illegal strike depends on the terms of the collective bargaining agreement, the issue falls into the intersection of arbitral and adininistra-

161. The Third Circuit made much of this issue in NLRB v. Pincus Bros., Inc-Maxwell, 620 F.2d 367 (3d Cir. 1980). Judge Rosenn, writing for the court, argued that the Spielberg test is a "discretionary adininistrative doctrine" and that the Board's decisions on whether to defer should therefore be reviewed under an "abuse of discretion" standard. 620 F.2d at 372 n.8. Accord NLRB v. South Cent. Bell Tel. Co., No. 81-4159, shp op. at 55 \& n.7 (5th Cir. Oct. 4, 1982) (citing cases from six circuits). Judge Garth vigorously disagreed and said that the "clearly repugnant" criterion of the Spielberg rule admits of no discretionary latitude and that therefore the Board's deferral decisions made under that criterion should be evaluated under an "error of law" standard. Id. at 380 (Garth, J., concurring). Judge Gibbons agreed with Judge Rosenn that there was no statutory basis for the Board's deferral policy; the policy was therefore a discretionary matter. Id. at 388 (Gibbons, J., dissenting); accord NLRB v. Plasterers' Local Union No. 79, 404 U.S. 116, 136-37 (1971).

The source of contention between Judges Rosenn and Garth seems to be that the Board's standard of deference under Spielberg is a self-imposed discretionary measure which requires an opinion of law as to the compatibility of the arbitral award and the NLRA in its applieation. Presumably, the "abuse of discretion" standard of review is higher than the "legal error" standard, but because Judge Rosenn found an abuse of discretion when Judge Garth found a legal error, the difference in standards of review was of no ultimate consequence in Pincus Brothers.

162. This conflict is dramatically illustrated in $N L R B$ v. Pincus Bros., Inc.-Maxwell, $620 \mathrm{~F} .2 \mathrm{~d}$ 367 (3d Cir. 1980). The majority of the court followed the letter of Spielberg and held that the arbitral award must stand even if it might be incorrect; given the need to encourage extra-legal dispute resolution, only clearly wrong awards are unworthy of deference. See id. at 374,377 (Garth, J., concurring). The dissent pointed to the Board's recent decision in Suburban Motor Freight, 247 N.L.R.B. 146 (1980), as evidence of the Board's intention to heighten its scrutiny under Spielberg of arbitral awards that reach statutory issues and noted with approval a trend in the District of Columbia Circuit to abide by the Board's decision not to defer in such cases. Pincus Brothers, 620 F.2d at 394, 396-97 (Gibbons, J., dissenting). See Banyard v. NLRB, 505 F.2d 342, 347-49 (D.C. Cir. 1974); Local 715, International Bhd. of Elec. Workers v. NLRB (Malrite of Wisconsin), 494 F.2d 1136, 1137-38 (D.C. Cir. 1974). But see Foumelle v. NLRB, 670 F.2d 331, 341-45 (D.C. Cir. 1982). A recent Fifth Circuit case lends further support to the position of the dissent in Pincus Brothers; the court in NLRB v. South Cent. Bell Tel. Co., No. 81-4159, slip op. (5th Cir. Oct. 4, 1982), held that the Board's decision not to defer should be sustained if the decision is reasonable and is not inconsistent with congressional labor policy. Id. at 57. The Pincus Brothers dissent deplored the position of the majority and that of the Ninth Circuit, see Douglas Aircraft Co. v. NLRB, 609 F.2d 352, 355 (9th Cir. 1979); Servair, Inc. v. NLRB, 102 L.R.R.M. 2705 (9th Cir. 1979), and argued that such inandatory deference to arbitral awards robs the Board of its jurisdiction to decide statutory issues. See Pincus Bros., 620 F.2d at 398 (Gibbons, J., dissenting). There is some indication that the Third Circuit has relaxed its position since Pincus Brothers, see NLRB v. General Warehouse Corp., 643 F.2d 965, $969-70$ (3d Cir. 1981), although the General Warehouse court explicitly denied any inconsistency, see id. at 970 n.20.

163. 29 U.S.C. $\$ 158(a)(3)(1976)$. 
tive/judicial jurisdiction. The discriminatory discipline in Hammermill Paper Co. v. $N L R B^{164}$ had been grieved to arbitration, but the Court of Appeals for the Third Circuit held that deference to the award in favor of the company was not required because the arbitrator did not decide the statutory issue of whether the employer violated section 8(a)(3). ${ }^{165}$ In Metropolitan Edison Co. v. $N L R B, 166$ there was no arbitration award in regard to the specific instance of discriminatory discipline at issue, but there had been two earlier awards on similar occasions in the past. The company argued that although the collective bargaining agreement in Metropolitan was the successor to those previously construed, its language in the relevant clause was identical to that of its predecessors, and that therefore the arbitral constructions of the earlier agreements were entitled to precedential effect. ${ }^{167}$ The Metropolitan court rejected this argument, holding that it was not bound by the previous awards because they governed only past instances of discriminatory discipline, not the case at hand. ${ }^{168}$ Thus the Court of Appeals for the Third Cir-

164. 658 F.2d 155 (3d Cir. 1981).

165. Id. at 161-62. The court held that the arbitrator addressed only the question of whether there was just cause for the representative's discipline, that is, whether his participation in the illegal work stoppage objectively warranted the punishment he received, rather than whether the punishment was unduly severe and discriminatory relative to the treatment of rank-and-file participants. Id. at 162. But see NLRB v. Motor Convoy, Inc., 673 F.2d 734, 736 (4th Cir. 1982).

The Board had a different explanation for its lack of deference in Hammermill Paper Co., 252 N.L.R.B. 1236 (1980), enforced, 658 F.2d 155 (3d Cir. 1981), petition for cert. filed, 50 U.S.L.W. 3703 (U.S. Jan. 1, 1982) (No. 81-1438). The Board concluded, as did the Third Circuit, that the arbitrator failed to reach the statutory question, id. at 1236-37; the Board also found, however, that the arbitrator disregarded material evidence and that the award was contrary to the NLRA. This latter conclusion justified under the Spielberg test the Board's refusal to defer to the arbitrator's opimion. See supra notes 158-60 and accompanying text. By explicitly following the rule of Monsanto Chemical, see supra note 158, the Third Circuit avoided the question of the fairness and legality of the arbitral proceedings. $658 \mathrm{~F} .2 \mathrm{~d}$ at $159-60$.

166. 663 F.2d 478 (3d Cir. 1981), cert. granted, 102 S. Ct. 2926 (1982).

167. Id. at 483. In one of the awards, the arbitrator ruled that union officials have an affirmative duty to uphold the collective bargaining agreement in the face of illegal action and that a breach of this duty, or even participation in an illegal strike, warranted liarslier punishment. Id.

168. There is a fundamental difference between deference to an arbitral award in a particular case and giving precedential effect to an award in subsequent cases, which would impermissibly give arbitrators the power to make common law. See supra note 157. The Metropolitan court noted that unless the collective bargaining agreeinent otherwise provides, arbitrators thenuselves are not bound by previous awards that construe the same agreement, because strict adherence to precedent would hinder the flexibility of an arbitration and controvert the parties' intent to resolve grievances on a case by case basis. 663 F.2d at 483-84. Accord NLRB v. South Cent. Bell Tel. Co., No. 81-4159, ship op. at 58 (5th Cir. Oct. 4, 1982). The agreement at issue in Metropolitan provided that arbitral decisions would be binding for the term of the agreement, but did not give binding effect to decisions under previous agreements. Id. at 484.

The Metropolitan court also held that the earlier arbitral awards concerned only the question of just cause for the discipline and did not raise the statutory issue of a possible violation of section 8(a)(3) of the NLRA, 29 U.S.C. § 158(a)(3) (1976). 663 F.2d at 483. Thus, the Metropolitan court could have followed Hammermill and based its refusal to defer on Monsanto Chemical. See stupra note 165 . 
cuit has in two instances declined to give effect to an arbitral award that would have permitted discriminatory discipline; yet in each case the court reserved judgment on the question of whether these awards were contrary to the purpose of section 8(a)(3) of the NLRA. ${ }^{169}$

An arbitration award on the issue of discriminatory discipline in the context of an illegal strike is likely to uphold the legitimacy of the discipline. The theory of negative leadership, which predicates an affirmative duty to dissuade on the union representative's status, is an arbitral concept. ${ }^{170}$ As Member Penello often pointed out, it is derived from the common law of the shop, and not from the exphicit terms of the collective bargaming agreement. 171 Although the common law of the shop is to be read into every collective bargaining agreement, 172 it ought not prevail when it conflicts with statutory policy as articulated by the NLRB and the courts. Deference to these arbitral awards as constructions of the collective bargaining agreement would resurrect the status-based theory of responsibility in its unost extreme form and stand on their heads the current holdings of the NLRB ${ }^{173}$ and the Courts of Appeals for the Third, Fifth, and Seventh Circuits. Nonetheless, this subversion of the contract-based theory of responsibility occurred in Fournelle v. NLRB. ${ }^{174}$

In Fournelle, the Court of Appeals for the District of Columbia Circuit rejected Metropolitan and held that a previous arbitration award on a similar occasion of discriminatory discipline definitively and bindingly construed the collective bargaining agreement to waive the union representative's right not to be punished more severely than the rank-and-file for participation in an illegal strike. ${ }^{175}$ As the Fournelle court noted, the arbitrator did not refer to any provision of

169. See Hammermill, 658 F.2d at 159; Metropolitan Edison, 663 F.2d at 483 n.4. By contrast, the administrative judge in Metropolitan Edison Co., 252 N.L.R.B. 1030 (1980), enforced, 663 F.2d 478 (3d Cir. 1981), cert. granted, 102 S. Ct. 2926 (1982), applied Spielberg and held that deference was not due the previous arbitral awards because, if made today, they probably would be repugnant to the NLRA. Id. at 1035 (opinion of administrative judge, enforced by Board).

170. See supra notes 27-29 and accompanymg text. See also Consolidation Coal Co., 263 N.L.R.B. No. 188, at $51-53$ \& 51 n.70 (1982) (Member Hunter, dissentimg). But see 263 N.L.R.B. No. 188, at 15 n.17; Rummage, supra note 19 at 274-75.

171. See, e.g., Gould Corp., 237 N.L.R.B. 881, 885-87 (1978) (Member Penello, dissenting), enforcement denied, 612 F.2d 728 (3d Cir. 1979), cert. denied, 449 U.S. 890 (1980). But see Consolidation Coal Co., 263 N.L.R.B. No. 188, at 41, 46 (1982) (Member Hunter, dissenting) (union representative's duty to dissuade is inherent in the no-strike clause).

172. See supra note 157 .

173. Even when it endorsed the status-based theory of implicit leadership, the Board rejected the theory of negative leadership as an illegal predication of punishment upon union status. See supra note 29 and accompanying text.

174. 670 F.2d 331 (D.C. Cir. 1982).

175. Id at 343-44. 
the agreement when he announced the waiver. The court, however, termed this deficiency "irrelevant" in hight of the arbitrator's power to supplement the terms of the agreement with the common law of the shop. ${ }^{176}$ The Board argued that an important protected right can only be waived by a clear and exphicit proviso; but the Fournelle court baldly stated that the arbitrator's opimon was perfectly clear and exphicit. 177 Thus, in the guise of enforcing the terms of the collective bargaining agreement, Fournelle completely reverts to a status-based theory of responsibility. The reversion is possible within the contract-based theory as long as an arbitrator can inject the common law of the shop into the contract regardless of its potential conflict with statutory policy.

The effect of Fournelle was recently limited in Szewczuga $v$. NLRB. ${ }^{178}$ In Szewczuga, the court explicitly followed the current position of the Courts of Appeals for the Third and Seventh Circuits and held that unless the collective bargaining agreeinent imposes on union representatives an affirmative duty to dissuade illegal strikers, representatives who participate in a strike cannot be punislied inore severely than rank-and-file participants. ${ }^{179}$ The Szewczuga court distinguislied Fournelle on the ground that the collective bargaining agreement in Fournelle did impose an affirmative duty to dissuade. ${ }^{180}$ This distinction puts the Court of Appeals for the District of Columbia Circuit in a soinewhat awkward position: it will rule against discriminatory discipline except where an arbitrator has ruled that sucl discrimination is authorized. ${ }^{181}$

By declining to decide in Hammermill and Metropolitan whether the arbitral awards which approved the discriminatory discipline were repugnant to section 8(a)(3) of the NLRA, ${ }^{182}$ the Court of Appeals for the Third Circuit weakened its position that the discipline violates sec-

176. Id. at $342-43$ n.20.

177. Id. at 343 n.21.

178. No. 81-1054, slip op. (D.C. Cir. Aug. 17, 1982).

179. Id. at 23.

180. Id. at 14.

181. Under Szewczuga, the arbitrator's decision must also be "sufficiently clear," id. at 16, and it unust be included in the administrative record, $i d$. at 15 , and raised as a defense to the charge of discriminatory discipline, id. at 15-16; see, e.g., Rickel Home Centers, 262 N.L.R.B. No. 93, at 2 (1982) (deferral to an arbitral award is an affirmative defense). Although an arbitrator upheld the discrimmatory discipline of the union representatives in Szewczuga, the employer did not make this decision part of the administrative record or raise it as a defense, and the court held that the employer could neither introduce this issue at the appellate level nor obtain a remand of the case for consideration of the arbitrator's decision. Szewczuga, No. 81-1054, slip op. at 15-20. According to the Szewczuga court, the arbitrator's decision that the discriminatory discipline was " "not contrary to the provisions of the collective bargaining agreenent," " $i d$. at 16 n.66 (quoting Brief for Petitioner at 14), was not sufficient to establish a contractual waiver of the representative's right not to be selectively punished. $I d$.

182. 29 U.S.C. \& 158(a)(3) (1976). See supra notes 165 \& 168 and accompanying text. 
tion 8(a)(3) unless it is predicated on an explicit term of the collective bargaining agreement. If the Court of Appeals for the Third Circuit had taken a stronger stance, the Fournelle court could not have rejected Metropolitan merely because Metropolitan holds that previous arbitration awards are not binding on subsequent questions of a similar nature. Rather, the Court of Appeals for the District of Columbia Circuit in Szewczuga would have been forced to acknowledge that its decision in Fournelle flies in the face of the Court of Appeals for the Third Circuit's substantive analysis of the legality of discriminatory discipline and effectively negates the trend towards a contract-based theory of responsibility. This trend began in the Third Circuit in Gould, Inc. v. $N L R B,{ }^{183}$ gamed inomentum in the Seventlı Circuit with C.H. Heist Corp. v. NLRB, ${ }^{184}$ and culminated in Metropolitan.

\section{Conclusion: The Supreme Court's Review of METROPOLITAN EDISON CO. V. NLRB}

In the spring of 1982, the Supreme Court granted certiorari to hear Metropolitan Edison Co. v. $N L R B .{ }^{185}$ The case presents three questions: (1) whether the NLRB and the courts may disregard clear, repeated arbitral imterpretations of a collective bargaining agreement; (2) whether union representatives have a higher duty than the rank-andfile to abide by the no-strike clause in a collective bargaining agreement, and if so, whether this higher duty includes the responsibility to try to end any illegal work stoppage; and (3) whether the employer commits an unfair labor practice if he discriminatorily disciplines a union representative for his failure to attempt to dissuade illegal strikers. ${ }^{186}$

The arguments that the various parties will make in the coming review of Metropolitan are not difficult to predict; how the Court will decide the issues presented, lowever, is inuch less clear. ${ }^{187}$ Given its high regard for arbitration, the Court may be persuaded that where contractual language remams unchanged in a series of collective bargaining agreements between the same parties, deference to an arbitrator's construction of that language should be expanded to grant

183. 612 F.2d 728 (3d Cir. 1979), cert. denied, 449 U.S. 890 (1980).

184. 657 F.2d 178 (7th Cir. 1981).

185. 663 F.2d 478 (3d Cir. 1981), cert. granted, 102 S.Ct. 2926 (1982).

186. Id. at $481-83$.

187. The only word froin the Court to date on the issue of discriminatory discipline of a union representative for his participation in an illegal work stoppage was Justice Powell's comment in a related context that such discrimination is "arguably . . . illegal." Complete Auto Transit, Inc. v. Reis, 451 U.S. 401, 421 (1981) (Powell, J., concurring in part \& in the judgment). 
precedential effect. This conclusion follows a simple logic that is intuitively, but deceptively, appealing.

In Metropolitan, the arbitrator in the earhier disputes was not construing language in the collective bargaining agreement when he decided that union representatives have a higher, affirmative duty in the context of an illegal strike. He was instead injecting into the contract the arbitral concept of negative leadership as part of the common law of the shop; but the NLRB has unequivocally rejected this concept as abhorrent to the statutory policy of the NLRA. In such a case, deference to an arbitral award may be tantamount to an illegal delegation of the Board's authority to determine a uniform national labor pohicy under the NLRA. In addition, there is a vital distinction between deferring to an arbitral award in a particular case, which pays the proper respect to the merits of voluntary, extra-legal dispute resolution, and giving precedential effect to awards that may conflict with established statutory policy, which raises arbitrators to judicial or admimistrative stature and binds the parties in a way not at all intended in an ordimary arbitration clause. Therefore, the Court in Metropolitan ought to temper its enthusiasin for arbitration by recognizing the inherent limitations of the arbitral process and the overriding need for a uniform national labor policy under the jurisdiction of the NLRB and the courts.

The statutory issue before the Court in Metropolitan is whether discriminatory discipline of union representatives for failing to dissuade illegal strikers violates section 8(a)(3) of the NLRA. This issue is linked to the question of whether union representatives have an affirmative duty to dissuade in the absence of a contractual provision that so specifies. This note endorses the position, most clearly articulated by the Court of Appeals for the Third Circuit, that union representatives should be held to no higher level of responsibility than that negotiated by the union and the company and exphicitly set forth in the collective bargaining agreement. To permit the einployer to unilaterally create and enforce at its own discretion a higher duty for union representatives, based on their status as such, is as unfair and capricious as it is illegal. If such discriminatory discipline is allowed without qualification, there will be no way to monitor the motives of employers for the antiunion animus which the Supreme Court long ago decided should be restrained, if not purged.

At the heart of the matter hes the "lawless vacuum"188 created by the absence of effective remedies for illegal work stoppages. The Court may be persuaded that the discriminatory discipline of union repre-

188. Id. at 423 . 
sentatives for their failure to dissuade illegal strikers is the only viable way to fill this vacuum and that when the recalcitrant union representatives participated in the stoppage, they are beyond the protection of the NLRA. As the Courts of Appeals for the Third and Seventh Circuits have noted, however, it may be impossible for a conscientious union representative to wholly refrain from any degree of participation in an illegal work stoppage and still be able to function as a inediator between the striking group and the employer. Soine would say that the union representative, as the leader of his work group, is in the best position to instigate an illegal work stoppage, but for the same reason, he may also be the inost able to stop an illegal strike once it has occurred-unless he is forced to detach and ahenate himself from the group at the very moment when his skill as a inediator is inost needed.

Of course, these practical considerations do not resolve the legal issue. The Court should resist the temptation to evaluate the effectiveness of discriminatory discipline as a deterrent to illegal work stoppages. Even if such a remedy is thought to be inore effective than not, it ought to be bargained for by the employer or created by legislative or administrative action. The legal issue that the Court will confront in Metropolitan raises its own array of conflicting demands. On the one hand, there is the established legal doctrine of withholding froin all participants in illegal strikes the statutory protections against employer discipline. On the other hand, there is the inandate of section 8(a)(3) of the NLRA, which unqualifiedly prohibits discriminatory discipline based on union status. It is certainly arguable that section $8(\mathrm{a})(3)$ should not protect rebellious representatives who engage in activities in contravention of the terms of the collective bargaining agreement. It is equally arguable that to deny union representatives the protection of section $8(a)(3)$ under any circumstances renders thein vulnerable to exactly the kind of antiunion attack on individual union representatives that the statute was created to prevent.

In a sense, tying the union representative's duty in the context of an illegal strike to the terms of the collective bargaining agreement represents a compromise position. Where it has been bargained for, the employer has full power to discipline union representatives who do not discharge their duty to dissuade illegal strikers. At the same time, the union representative is protected from arbitrary or unwarranted discipline directed at him solely on the basis of his union status. By predicating the representative's liability on the explicit terms of the agreeinent, the Supreme Court can give effect to the national labor pol- 
icy that bargaining, not unilateral action, should define the rights and responsibilities of those bound by the agreement.

Susan J. Cole 